\title{
Liquid fertilizer products from anaerobic digestion of food waste: mass, nutrient and energy balance of four digestate liquid treatment systems
}

\author{
Elina Tampio $^{\mathrm{a}, \mathrm{b}, 1}$, Sanna Marttinen ${ }^{\mathrm{c}}$, Jukka Rintala $^{\mathrm{b}}$
}

${ }^{a}$ Natural Resources Institute Finland (Luke), Bio-based Business and Industry, Tietotie 2 C, FI-31600, Jokioinen, Finland

${ }^{b}$ Tampere University of Technology, Department of Chemistry and Bioengineering, P.O. Box 541, FI-33101 Tampere, Finland

${ }^{c}$ Natural Resources Institute Finland (Luke), Bio-based Business and Industry, Viikinkaari 4, FI-00790, Helsinki, Finland

\begin{abstract}
This study compared four different digestate liquid treatment systems of a theoretical anaerobic digestion plant in order to facilitate the utilization of municipal food waste nutrients in agriculture. The mass, nutrient and energy balances of a theoretical plant digesting $60 \mathrm{kt} / \mathrm{y}$ of food waste were used to evaluate the feasibility of the treatments to concentrate nutrients into liquid fertilizer products. The studied technologies for digestate liquid treatment were ammonia stripping, ammonia stripping combined with reverse osmosis (RO), evaporation combined with $\mathrm{RO}$, and stripping combined with both evaporation and RO. As a result, processing of digestate into concentrated fertilizer products consumed less than $10 \%$ of the produced energy from food wastes and was also sufficient for the heat-demanding digestate liquid treatments, evaporation and stripping. The digestate liquid treatment systems were considered as nitrogen and potassium concentration methods which were able to concentrate up to

\footnotetext{
${ }^{1}$ Corresponding author. Tel.: +358 29532 6573, E-mail address: elina.tampio@luke.fi
} 
$67 \%$ of the feedstock nitrogen into transportable fertilizer products with low mass. Of the studied digestate systems evaporation combined with RO was evaluated as the most efficient nutrient recovery technology for the production of transportable fertilizer products due to the high concentration of nutrients and nutrient availability as well as low product mass and energy consumption. Overall, the selection of the treatment technology is dependent on the location of the anaerobic digestion plant relative to the agricultural land and the type of fertilizer products needed.

\section{Keywords}

Anaerobic digestion, food waste, digestate liquid treatment, stripping, evaporation, reverse osmosis 


\section{Introduction}

Anaerobic digestion (AD) of food waste (FW) is increasingly used to produce renewable energy, in the form of heat and power or vehicle fuel, and nutrient-rich digestate for agriculture, to decrease the use of energy intensive mineral fertilizers (Laureni et al., 2013). However, the digestate has usually unbalanced nutrient ratios for plant growth (Camilleri-Rumbau et al., 2014). Large mass due to high water content increases the transportation need of the digestate, as the AD plants treating municipal FW are usually located far from agricultural lands (Babson et al., 2013). Digestate treatment by solid-liquid separation is an increasingly used treatment for the production of phosphorus containing solid digestate and liquid digestate containing water-soluble nitrogen and potassium. The solid-liquid separation of the digestate divides most of the mass into the liquid fraction decreasing its nutrient concentrations (Hjorth et al., 2010). Low nutrient concentrations and large mass complicate the use of the liquid digestate in agriculture and increase the transportation need (Chiumenti et al., 2013). To efficiently utilize the FW nutrients, the treatment of liquid digestate is needed to decrease its mass and increase nutrient concentrations.

The digestate liquid can be treated to remove water and simultaneously concentrate nutrients. This lowers the environmental impact (i.e. global warming potential and acidification) and reduces transportation costs to areas with nutrient deficits compared with digestate use as such (Rehl and Müller, 2011). In addition to the decreased transportation costs, the additional economic benefits of the digestate liquid treatment are related to the profit gained from the selling of the fertilizers (Fuchs and Drosg, 2013, Rehl and Müller, 2011). With the combination of solid-liquid separation and digestate liquid treatment, fertilizer products with optimal composition can be 
produced (Hjorth et al., 2010). Produced fertilizers can be designed to match the crop nutrient requirements and to achieve better control of the nutrient contents of the applied fertilizer to reduce the nutrient run-off and leaching. These products could be also used to supplement the raw digestate fertilization by replacing mineral fertilizers.

Technologies for digestate liquid treatment such as ammonia stripping, evaporation, struvite precipitation, membrane separation, as well as various combinations of these, have been previously studied considering nutrient recovery and production of nutrient-rich products with, e.g., digestate liquids, manure and urine (Antonini et al., 2011, Bonmatí et al., 2003, Bonmatí and Flotats, 2003a, b, Chiumenti et al., 2013, Ek et al., 2006, Ledda et al., 2013). However, to ensure the usability and sustainability of different digestate liquid treatment techniques and to facilitate the agricultural utilization of the nutrients over longer transportation distances, the total digestate treatment chain and all produced mass flows should be taken into consideration as well as all the process inputs, e.g., chemicals and energy (Mehta et al., 2015). As life cycle assessment and energy efficiency studies have mainly concentrated on the use of raw digestate or separated solid digestate (e.g. Bacenetti et al., 2013, Berglund and Börjesson, 2006, Evangelisti et al., 2014, Pöschl et al., 2010, Smyth et al., 2009) only a few studies exist where the digestate liquid and its treatment has been taken into consideration (Rehl and Müller, 2011). In addition, these life cycle studies focus solely on environmental and ecological effects and do not evaluate the fertilizer products from the viewpoint of biogas plant efficiency or agriculture and plant nutrition. From these perspectives information about the mass, nutrient and energy balances of an $\mathrm{AD}$ plant with digestate liquid treatment is important, in addition to environmental aspects. 
The aim of this study was to compare the potential of four digestate liquid treatment systems of a theoretical $\mathrm{AD}$ plant digesting municipal $\mathrm{FW}$ to produce fertilizer products with low water and concentrated nutrient contents. The studied treatment systems were different combinations of ammonia stripping, evaporation and membrane filtration, which have been applied in the full scale treatment of digestate or manure based liquids (see e.g. Boehler et al., 2015, Flotats et al., 2011, Fuchs and Drosg, 2013). For all four systems the mass, nutrient and energy balances were calculated and the nutrient recovery, mass reduction and energy efficiencies were compared based on typical literature values from laboratory, pilot and full scale studies. The performance of the treatment systems was also assessed in relation to the energy consumption of fertilizer product transportation to see the effect of digestate liquid treatment on the transportability of the products.

\section{Materials and methods}

\subsection{Overview of the theoretical AD plant}

This study investigated a theoretical mesophilic AD plant which was assumed to digest source-segregated municipal FW (60 kt/y, kilotonnes per year). Figure 1 presents the applied $\mathrm{AD}$ plant system boundaries which include pretreatment, a digester, digestate treatment and biogas upgrading. The FW was pretreated and hygienized $(1 \mathrm{~h}$ at $70{ }^{\circ} \mathrm{C}$ ) and subsequently diluted to a total solids (TS) content of $15 \%$ with processed water or water from the local water supply. The digestate treatment was assumed to include the separation of the digestate into liquid and solid digestates using a centrifuge. The liquid digestate was assumed to be treated with one of the four digestate liquid treatment systems consisting of ammonia stripping, evaporation and membrane (reverse osmosis, RO) technologies (Figure 2). The formed biogas was assumed to be upgraded 
in a combined heat and power unit (CHP) into heat and electricity to be used in the AD plant and the excess electricity was to be fed to the power grid.

\subsection{Pretreatment, hygienization, AD and gas upgrading}

\subsubsection{Mass and nutrient balances}

The feed for AD was based on the characteristics of source-segregated FW: TS $25 \%$, volatile solids (VS) $23 \%$, Ntot $7.5 \mathrm{~kg} / \mathrm{tFM}$ (fresh matter), $\mathrm{NH}_{4}-\mathrm{N} 0.4 \mathrm{~kg} / \mathrm{tFM}$, Ptot $0.9 \mathrm{~kg} / \mathrm{tFM}$, Ktot $2.8 \mathrm{~kg} / \mathrm{tFM}$ (Tampio et al., 2014, 2015). The FW (60 kt/y) was assumed to be pretreated as in Banks et al., (2011) by shredding/maceration and then hygienized $\left(1 \mathrm{~h}\right.$ at $70{ }^{\circ} \mathrm{C}$ according to European Council, 2011, European Parliament and the Council, 2009). Pretreatment and hygienization were not considered to affect the FW mass and nutrient content as material was not removed during the pretreatment step. The dilution water was assumed to be added to the FW during the maceration step (40 kt/y water to achieve TS of $15 \%$, mixture referred to as feedstock). The mass of the produced digestate was calculated by subtracting the mass of the biogas from the feedstock (60 kt of FW $+40 \mathrm{kt}$ of dilution water). The calculation of the biogas mass was based on biogas composition $\left(60 \% \mathrm{CH}_{4}, 40 \% \mathrm{CO}_{2}\right)$ and component densities $\left(\mathrm{CH}_{4}\right.$ $0.72 \mathrm{~kg} / \mathrm{m}^{3}, \mathrm{CO}_{2} 1.96 \mathrm{~kg} / \mathrm{m}^{3}$, see Supplementary material for calculations). In the digestate, the total nutrient concentrations (Ntot, Ptot, Ktot, $\mathrm{kg} / \mathrm{tFM}$ ) were assumed to be the same as in the feedstock, while the ammonium nitrogen in FW was assumed to increase from $0.4 \mathrm{~kg} / \mathrm{tFM}$ to $4 \mathrm{~kg} / \mathrm{tFM}$ after digestion (Tampio et al., 2014, 2015).

\subsubsection{Energy balance}

The energy balance included both heat and electricity consumption and production in the AD plant. The amount of thermal energy (th) needed for heating the 
FW (60 kt) to $75{ }^{\circ} \mathrm{C}$ to maintain the required temperature during hygienization was calculated assuming the specific heat capacity of the feedstock to be the same as that of water $\left(4.18 \mathrm{~kJ} / \mathrm{kg}^{\circ} \mathrm{C}\right.$, see Supplementary material for calculations). The heat energy from the hygienization was assumed to be sufficient for the mesophilic $\left(40{ }^{\circ} \mathrm{C}\right)$ digester (Berglund and Börjesson, 2006, Prapaspongsa et al., 2010) and thus, no additional heating was allocated for the heating of FW prior to the digester. However, the heating of the dilution water $(40 \mathrm{kt} / \mathrm{y})$ was calculated with the specific heat capacity of water using temperature difference from 15 to $40{ }^{\circ} \mathrm{C}$. Heat losses from the hygienization and digester units were assumed to be in total $15 \%$ of the heat demand (digester heat loss $15 \%$ in Smyth et al., 2009, 20\% in Rapport et al., 2011) being dependent on the reactor design as well as the difference between the reactor and outdoor temperature. The electricity (el) consumption of $37.5 \mathrm{kWh} / \mathrm{tFM}$ feedstock for the hygienization and pretreatment unit (reviewed in Pöschl et al. 2010, see Supplementary material), and 18 $\mathrm{kWh} / \mathrm{tFM}$ for the digester was used (reviewed in Berglund and Börjesson, 2006, reviewed in Pöschl et al., 2010, see Supplementary material).

The energy content (MWh/y) of the produced biogas was calculated by multiplying the biochemical methane potential of the FW (BMP, $450 \mathrm{~m}^{3} \mathrm{CH}_{4} / \mathrm{tVS}$, Tampio et al. 2014) with the amount of feedstock VS fed to the reactor. The conversion factor of $1 \mathrm{~m}^{3}\left(\mathrm{CH}_{4}\right)=10 \mathrm{kWh}$ was used. For the conversion of the biogas into heat and electricity in the CHP unit, the energy conversion efficiencies of $38 \%$ for electricity and $48 \%$ for heat were used (Bacenetti et al., 2013, Poeschl et al., 2012). Additionally, for the CHP-unit electricity the consumption of 5\% of the energy produced in CHP was applied (Banks et al., 2011, Havukainen et al., 2014, Naegele et al., 2012, Pöschl et al., 2010, see Supplementary material). However, the use of different desulfurization 
methods for the biogas prior to CHP can increase the energy consumption, which was not taken into consideration in this study. E.g. in Karellas et al. (2010) the combined desulfurization with a spray scrubber and CHP was reported consuming $15 \%$ of the electricity produced in $\mathrm{CHP}$ in an $\mathrm{AD}$ plant treating pig manure, wheat straw and glycerol (45 kt/y).

\subsection{Digestate treatment}

The digestate was assumed to be separated with a decanter centrifuge producing liquid and solid fractions of which the liquid fraction was further treated to produce fertilizer products. The solid digestate was assumed to be used as such in agriculture, as it is the practice e.g. in the UK, Scandinavia and Switzerland, where the legislation does not require further treatment with e.g. composting (Saveyn and Eder 2014). Centrifuge separation efficiencies for mass, TS, VS and nutrients (Ntot, $\mathrm{NH}_{4}-\mathrm{N}$, Ptot, Ktot) were adopted from the literature and the electricity consumption was assumed to be 3.5 kWh/tFM digestate (Flotats et al., 2011, reviewed in Hjorth et al., 2010, Ledda et al., 2013, Møller et al., 2000, 2002, Table 1, see Supplementary material). Polymer/flocculent additions used in separation were not included in the mass balance as the annual total amount of additions was considered negligible (for example 1.625

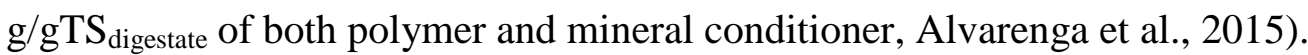

It was assumed that all outputs from the different digestate liquid treatment systems were suitable for agricultural use and/or processed water suitable for discharging (Figure 2). Processed water was used as dilution water before the digester and the surplus water was assumed to be discharged. Additional treatments of processed water with, e.g., active carbon filters (Zarebska et al., 2015) were not taken into 
consideration. With each treatment system, the consumption of chemicals $(\mathrm{NaOH}$, $\mathrm{H}_{2} \mathrm{SO}_{4}, \mathrm{~m}^{3} / \mathrm{y}$ ) was included in the calculation of the output mass and characteristics.

\subsubsection{Reference system, SO}

In the reference system (referred as S0), the digestate liquid did not undergo any treatment after digestate separation (Figure 2). Thus, due to the lack of liquid treatment, the water for feedstock dilution came from the local water supply, i.e., outside the system boundaries. The digestate liquid was not used for dilution due to the high nitrogen content which could accumulate during digestion and inhibit the process.

\subsubsection{Stripping, $S 1$}

Ammonia stripping combined with $\mathrm{H}_{2} \mathrm{SO}_{4}$ scrubbing (system referred to as $\mathrm{S} 1$ ) was studied to produce ammonium sulfate and stripping residue (Figure 2). During stripping, $\mathrm{NH}_{4}-\mathrm{N}$ is transformed to $\mathrm{NH}_{3}$ along with the temperature and a $\mathrm{pH}$ increase and further recovered with $\mathrm{H}_{2} \mathrm{SO}_{4}$ in the form of ammonium sulfate $\left(\left(\mathrm{NH}_{4}\right)_{2} \mathrm{SO}_{4}\right)$ during scrubbing. In the mass and nutrient balance calculations the nitrogen $\left(\mathrm{NH}_{4}-\mathrm{N}\right)$ recovery efficiency was assumed to be $95 \%$ based on laboratory, pilot and full scale studies (Basakcilardan-Kabakci et al., 2007, Bonmatí and Flotats, 2003a, Flotats et al., 2011, Guštin and Marinšek-Logar, 2011, Laureni et al., 2013, Liu et al., 2015, Table 1, see also Supplementary material). $\left(\mathrm{NH}_{4}\right)_{2} \mathrm{SO}_{4}$ was assumed to be a chemically pure product with no TS, VS, Ptot or Ktot, while the Ntot was assumed to consist solely of the $\mathrm{NH}_{4}$ $\mathrm{N}$. The $\mathrm{NH}_{4}-\mathrm{N}$ mass balance was based on the assumption that the $\mathrm{NH}_{4}-\mathrm{N}$ concentration in the produced ammonium sulfate was $40 \mathrm{~kg} / \mathrm{tFM}$ (Laureni et al., 2013). The energy consumption during stripping consisted of the heat energy for the temperature increase from the digester to the stripper (from 40 to $80{ }^{\circ} \mathrm{C}$ ) which was calculated using the 
specific heat capacity of water. Electricity consumption for stripping of $2 \mathrm{kWh} / \mathrm{kgN}$ recovered was used (reviewed in van Eekert et al., 2012, Table 1, see Supplementary material). The stripping was assumed to be executed in atmospheric pressure and thus, no energy consumption for the production of vacuum was allocated. $\mathrm{NaOH}(50 \%)$ consumption for the $\mathrm{pH}$ increase before stripping was assumed to be the same as the $\mathrm{pH}$ increase of urine ( $\mathrm{pH}$ from 9 to $10,20 \mathrm{~L} / \mathrm{m}^{3}$, Antonini et al., 2011). $\mathrm{NaOH}$ consumption could be reduced with $\mathrm{CO}_{2}$ stripping before ammonia stripping (Boehler et al., 2015), which was, however, not taken into consideration in this study. The $\mathrm{H}_{2} \mathrm{SO}_{4}(93 \%)$ consumption during ammonia stripping was calculated using the molar ratios of $\mathrm{H}_{2} \mathrm{SO}_{4}$ and $\left(\mathrm{NH}_{4}\right)_{2} \mathrm{SO}_{4}$ and the nitrogen concentration of $40 \mathrm{~kg} / \mathrm{tFM}$ in the ammonium sulfate, from which the consumption of $0.08 \mathrm{~m}^{3} / \mathrm{t}$ liquid digestate was used.

\subsubsection{Stripping and reverse osmosis, $S 2$}

Ammonia stripping was combined with reverse osmosis treatment (system referred as S2) to produce ammonium sulfate, retentate and processed water (Figure 2). After stripping, the stripping residue was directed to the RO treatment producing processed water flow for discharge. For stripping treatment, the mass and nutrient separation/recovery efficiencies, chemical and energy consumptions calculations were based on the same values as in system S1 (Table 1). The mass and nutrient balances for the RO treatment were calculated based on the typical values from the literature (Table 1) and the electricity use of $2.5 \mathrm{kWh} / \mathrm{t}$ stripping residue was applied (Carretier et al., 2015, Chiumenti et al., 2010, Ek et al., 2006, Flotats et al., 2011, Ledda et al., 2013, Mondor et al., 2008, see Supplementary material). The regeneration and/or change of RO membranes were not taken into consideration.

\subsubsection{Evaporation and reverse osmosis, $S 3$}


Evaporation combined with RO (referred as S3) was studied to concentrate nutrients in the liquid digestate and a major part of the liquid into condensate which was further treated with $\mathrm{RO}$ to produce retentate. The retentate was in turn recycled back to separation, and processed water was directed to discharge (Figure 2). The $\mathrm{pH}$ of the digestate liquid was controlled with $\mathrm{H}_{2} \mathrm{SO}_{4}$ to prevent the volatilization of $\mathrm{NH}_{4}{ }^{+}$during evaporation where the liquid was heated to $80{ }^{\circ} \mathrm{C}$. The mass and nutrient balance calculations for the evaporation were based on typical literature values from laboratory, pilot and full scale studies (Bonmatí and Flotats, 2003b, Chiumenti et al., 2013, Ek et al., 2006, Flotats et al., 2011, Mauer et al., 2003, Table 1, see also Supplementary material). The TS and VS separation efficiencies in the concentrate were assumed to be $100 \%$ and the $\mathrm{NH}_{4}-\mathrm{N}$ recovery rate the same as in $\mathrm{Ntot}(80 \%)$. The $\mathrm{H}_{2} \mathrm{SO}_{4}(93 \%)$ consumption of $0.005 \mathrm{~m}^{3} / \mathrm{t}$ digestate liquid for the $\mathrm{pH}$ decrease during evaporation was based on the $\mathrm{pH}$ decrease of urine and manure with strong $\mathrm{H}_{2} \mathrm{SO}_{4}$ (pH from 9 to 6 in Ek et al., 2006, pH from 7.2 to 5.5 in Sørensen and Eriksen, 2009). The consumption of other chemicals such as antifoaming additives was not included. The energy consumption of evaporation consisted of the heat energy needed to increase the digestate liquid temperature from 40 to $80{ }^{\circ} \mathrm{C}$ plus the electricity consumption of 5 $\mathrm{kWh} / \mathrm{t}$ liquid digestate based on typical literature values (Bonmatí and Flotats, 2003b, Chiumenti et al., 2013, Ek et al., 2006, Flotats et al., 2011, Mauer et al., 2003, Table 1, see also Supplementary material). No vacuum conditions for the evaporation were applied as the process temperature was high $\left(80{ }^{\circ} \mathrm{C}\right)$. Mass and nutrient separation/recovery efficiencies, chemical and energy consumptions considering RO were the same as in $\mathrm{S} 2$.

\subsubsection{Stripping, evaporation and $\mathrm{RO}, \mathrm{S} 4$}


Combined stripping, evaporation and RO (S4) were studied to produce both ammonium sulfate and concentrate. After stripping, the stripping residue was evaporated to produce concentrate and condensate. The condensate was treated in RO after which the retentate was further recycled back to digestate separation and the processed water was discharged (Figure 2). The same mass and nutrient separation/recovery efficiencies, chemical and energy consumptions for stripping were used as in system S1, for evaporation as in system S3 and for RO as in system S2 (Table 1). However, it was assumed that heat from the stripping $\left(80{ }^{\circ} \mathrm{C}\right)$ was sufficient for the evaporation and thus, no heat energy was allocated for evaporation (Ervasti et al., 2011).

In systems S1-S4, no heat losses were calculated for stripping and evaporation, nor the energy consumption of the membrane changes for $\mathrm{RO}$, due to the lack of reference data in the literature. As the operational temperatures were the same in stripping and evaporation $\left(80^{\circ} \mathrm{C}\right)$, the effect of heat losses in the total energy balances between systems S1-S3 was assumed to be relatively small. In the full scale stripping and evaporation plants the heat losses due to the convection and radiation through treatment apparatus, and through the evaporation of material, are reduced with the insulation and use of heat exchangers.

\subsection{Transportation}

The energy consumption during the transportation of the fertilizer products from the digestate liquid treatments was calculated using the energy consumption of a semitrailer truck in Finland, $0.17 \mathrm{kWh} / \mathrm{t}-\mathrm{km}$ (full 25t load, EURO 5 truck type, VTT, 2012). The transportation of liquid products from each digestate liquid treatment systems was studied from 0 to $250 \mathrm{~km}$. 


\section{Results}

\subsection{Mass and nutrient balance of $\mathrm{AD}$ and digestate treatment}

The mass and nutrient flows of digestate and digestate liquid treatments formed the mass and nutrient balance of the systems showing the concentration of nutrients into fertilizer products. The calculations were based on the mass flow of the feedstock (FW + diluting water) and added chemicals as well as the characteristics of the digestate. The mass of the digestate accounted for $87 \%$ of the initial feedstock fed to the AD plant (60 kt of FW $+40 \mathrm{kt}$ of dilution water), while $13 \%$ of the feedstock was transformed into biogas during $\mathrm{AD}$. The digestate separation produced liquid $(79 \mathrm{kt} / \mathrm{y})$ more than eight times the amount of solid digestate (9 kt/y) (Table 2, Table 3).

The treatment of the digestate liquid with stripping (S1) concentrated $45 \%$ of the initial feedstock nitrogen into ammonium sulfate $(40 \mathrm{~kg} / \mathrm{tFM})$ with the mass of $11 \mathrm{kt} / \mathrm{y}$ (Table 2, Table 3). The mass of the ammonium sulfate accounted for only $5 \%$ of the feedstock mass flow when the chemical additions were not considered (Table 3 ). The remaining stripping residue flow was $85 \mathrm{kt} / \mathrm{y}$ with low nitrogen concentration $(1.5$ $\mathrm{kgN} / \mathrm{tFM})$ compared with the untreated digestate liquid $(4.0 \mathrm{kgN} / \mathrm{kgFM})$ but with comparable in the concentrations of both phosphorus $(0.1 \mathrm{kgP} / \mathrm{tFM}$ in the stripping residue and digestate liquid) and potassium (1.9 $\mathrm{kgK} / \mathrm{tFM}$ in the stripping residue, 1.8 $\mathrm{kgK} / \mathrm{tFM}$ in the digestate liquid). In total, the amount of outputs from the stripping

system was $85 \mathrm{kt} / \mathrm{y}$ (ammonium sulfate + stripping residue, Table 2) which was $70 \%$ of the feedstock nitrogen, $10 \%$ of phosphorus, $85 \%$ of potassium and $79 \%$ the feedstock mass without chemical additions (Table 3 ). 
In combined stripping $+\mathrm{RO}$ treatment $(\mathrm{S} 2)$, stripping produced the same amount of ammonium sulfate as in a system with stripping only (S1, $11 \mathrm{kt} / \mathrm{y})$, while the RO treatment of stripping residue produced retentate and processed water flows of $21 \mathrm{kt} / \mathrm{y}$ and $53 \mathrm{kt} / \mathrm{y}$, respectively (Table 2). The retentate still contained nutrients $(5.4 \mathrm{kgN} / \mathrm{tFM}$, $0.2 \mathrm{kgP} / \mathrm{tFM}, 6.9 \mathrm{kgK} / \mathrm{tFM}$ ), and was assumed to be used as fertilizer in agriculture (as in Ledda et al., 2013), and not recycled within the digestate liquid treatment as in systems S3 and S4. Thus, in this system the mass of the fertilizer products (ammonium sulfate, retentate) was $32 \mathrm{kt} / \mathrm{y}$ (Table 2), and concentrated $70 \%$ of the feedstock nitrogen, $10 \%$ of phosphorus and $84 \%$ of potassium into $26 \%$ of the feedstock mass without chemical additions (Table 3).

Evaporation treatment combined with RO (S3) produced only $16 \mathrm{kt} / \mathrm{y}$ of nutrientrich concentrate (17.9 $\mathrm{kgN} / \mathrm{tFM}, 0.3 \mathrm{kgP} / \mathrm{tFM}, 9.0 \mathrm{kgK} / \mathrm{tFM})$. Subsequently, RO treatment produced $18 \mathrm{kt} / \mathrm{y}$ of retentate and $45 \mathrm{kt} / \mathrm{y}$ of processed water from the condensate (Table 2). Without chemical additions the fertilizer product from system S3 (concentrate) accounted for $63 \%$ of the feedstock nitrogen, $10 \%$ of phosphorus, $85 \%$ of potassium and $16 \%$ of the feedstock mass (Table 3).

When stripping and evaporation were combined with RO (S4) two fertilizer product flows, ammonium sulfate and concentrate, were produced as well as retentate and processed water $(11 \mathrm{kt} / \mathrm{y}, 15 \mathrm{kt} / \mathrm{y}, 16 \mathrm{kt} / \mathrm{y}, 42 \mathrm{kt} / \mathrm{y}$, respectively, Table 2). In total, with fertilizer products, ammonium sulfate and concentrate, $67 \%$ of the nitrogen, $10 \%$ of phosphorus and $85 \%$ of potassium from the feedstock was recovered and concentrated into $20 \%$ of the mass flow of the feedstock, when the chemical additions were not considered (Table 3). The nitrogen recovery of $67 \%$ in S4 was $3 \%$ lower compared with system S1 with stripping, which was due to the produced retentate and 
processed water flows in S4, which contained traces nitrogen but were not considered as fertilizer products. The nutrient concentrations in the concentrate from S4 were similar to the concentrate from $\mathrm{S} 3(0.3-0.4 \mathrm{kgP} / \mathrm{tFM}, 9-9.6 \mathrm{kgK} / \mathrm{tFM})$, except for the nitrogen content, which was for the most part recovered with stripping (6.8 $\mathrm{kgN} / \mathrm{tFM}$ in $\mathrm{S} 4,17.9$ $\mathrm{kgN} / \mathrm{tFM}$ in S3, Table 2).

The efficiency of the four liquid digestate treatment systems in concentrating nitrogen from the feedstock into fertilizer products was assessed with the ratio between the recovered nitrogen ( $\%$ of the feedstock) and the recovered mass ( $\%$ of the feedstock, from Table 3). The resulting efficiencies were 0.9 for systems S0 and S1 and 2.7, 4.0 and 3.4 for systems S2, S3 and S4, respectively, where the increasing ratio demonstrates increasing the concentration of nitrogen into products with low mass. The most efficient system for the digestate liquid treatment was $\mathrm{S} 3$, combining both evaporation and $\mathrm{RO}$ to produce a fertilizer product with low mass and high nitrogen concentration.

\subsection{Energy balance}

The energy production in $\mathrm{AD}$ was based on the methane production of the FW, around $62 \mathrm{GWh}$ per year, which was utilized in CHP for the production of electricity (24 $\left.\mathrm{GWh}_{\mathrm{el}} / \mathrm{y}\right)$, and heat $\left(29 \mathrm{GWh}_{\mathrm{th}} / \mathrm{y}\right.$, Table 4). In total, $\mathrm{AD}$ consumed $9 \%$ of the produced total energy as electricity for pretreatment and hygienization of the feedstock (2250 $\left.\mathrm{MWh}_{\mathrm{el}} / \mathrm{y}\right)$, gas conversion in $\mathrm{CHP}\left(1180 \mathrm{MWh}_{\mathrm{el}} / \mathrm{y}\right)$ and digestion (1860 $\left.\mathrm{MWh}_{\mathrm{el}} / \mathrm{y}\right)$. The heat consumption of the $\mathrm{AD}$ in total was $10 \%$ of the produced total energy including hygienization (4200 $\left.\mathrm{MWh}_{\mathrm{th}} / \mathrm{y}\right)$, digester (1200 $\left.\mathrm{MWh}_{\mathrm{th}} / \mathrm{y}\right)$ and heat losses (800 $\left.\mathrm{MWh}_{\mathrm{th}} / \mathrm{y}\right)($ Table 4). 
All the four studied digestate treatment systems (S1-S4) and the reference system (S0) included solid-liquid separation with a centrifuge, which used $300 \mathrm{MWh}$ of electricity per year $(0.5 \%$ of the produced energy, Table 4$)$ as the material electricity consumption was calculated per produced digestate. The digestate stripping (S1, S2) had an electricity demand of $400 \mathrm{MWh}_{\mathrm{el}} / \mathrm{y}$, while the addition of the RO treatment (S2) increased the electricity demand by $190 \mathrm{MWh}_{\mathrm{el}} / \mathrm{y}$ (total $590 \mathrm{MWh}_{\mathrm{el}} / \mathrm{y}$ in $\mathrm{S} 2$ ). Evaporation (S3) consumed a similar amount as stripping and the electricity consumption of RO was $160 \mathrm{MWh}_{\mathrm{el}} / \mathrm{y}$ (total $550 \mathrm{MWh}_{\mathrm{el}} / \mathrm{y}$ in $\mathrm{S} 3$ ). In the system combining stripping + evaporation $+\mathrm{RO}(\mathrm{S} 4)$, the electricity consumption in total was $920 \mathrm{MWh}_{\mathrm{el}} / \mathrm{y}$, which accounted $1.5 \%$ of the energy produced in AD. The heat demand in all four studied treatment systems (S1-S4) was similar, around $3700 \mathrm{MWh} / \mathrm{y}$ (6\% of the produced energy in AD), as the heat consumption for both stripping and evaporation was similar, RO did not use any heat, and in the system combining stripping + evaporation + RO (S4) the heat demand was allocated only for stripping (Table 4).

The total energy consumption of the digestate liquid treatment systems increased from systems $\mathrm{S} 1$ to $\mathrm{S} 4$ as the units in the treatment of digestate liquid increased being 4100, 4300, 4200 and $4600 \mathrm{MWh} / \mathrm{y}$ in systems S1, S2, S3 and S4, respectively (Table 4). The combined energy consumption of the digestate treatment systems and AD was 15.9-16.4 GWh, which accounted for $26 \%$ of the total energy produced.

The energy consumption of the digestate liquid treatment per recovered nitrogen in the concentrated fertilizer products (ammonium sulfate, concentrate) were the lowest $(150 \mathrm{kWh} / \mathrm{kgN})$ with the following systems: evaporation $+\mathrm{RO}(\mathrm{S} 3)$; stripping + evaporation + RO (S4) (Table 4). In systems with stripping (S1 and S2) the energy consumption was higher $(200-210 \mathrm{kWh} / \mathrm{kgN})$ due to the lower amount of nitrogen in 
the produced ammonium sulfate compared with the products from systems S3 and S4. However, when only electricity consumption was taken into consideration, the evaporation $+\mathrm{RO}(\mathrm{S} 3)$ and stripping (S1) had lower electricity consumptions per recovered nitrogen (19-20 $\mathrm{kWh}_{\mathrm{e}} / \mathrm{kgN}$ in $\mathrm{S} 1$ and $\mathrm{S} 3$, around $30 \mathrm{kWh}_{\mathrm{e}} / \mathrm{kgN}$ in $\mathrm{S} 2$ and $\mathrm{S} 4$, Table 4) as the electricity demand per year was low and nitrogen recovery efficiency higher compared with the systems stripping + RO (S2) and stripping + evaporation + $\mathrm{RO}(\mathrm{S} 4)$.

\subsection{Transportation of fertilizer products}

The energy consumption associated with the transportation of the fertilizer products in the digestate liquid treatment systems (S0-S4) was evaluated in relation to the increasing transportation distance (from 10 to $250 \mathrm{~km}$, Figure 3 ). Of the studied products, the concentrate from the evaporation treatment (S3) used less than 700 $\mathrm{MWh} / \mathrm{y}$ during $250 \mathrm{~km}$ transportation, and was considered as the most energy efficient to transport longer distances. In contrast, the transportation the digestate liquid as such (S0) and stripping residue from S1 consumed the largest amount of energy (around 700 $\mathrm{MWh} / \mathrm{y}$ transportation distance $50 \mathrm{~km}, 3300-3600 \mathrm{MWh} / \mathrm{y}$ distance $250 \mathrm{~km}$ ) (Figure 3, Table 2).

\section{Discussion}

\subsection{Energy consumption of AD, digestate liquid treatment and transportation}

The present results, based on typical literature values from laboratory, pilot and full scale studies, show that the processing of digestate through solid-liquid separation and digestate liquid treatments into concentrated fertilizer products consumed less than $10 \%$ of the produced energy in an $\mathrm{AD}$ plant treating $60 \mathrm{kt} / \mathrm{y}$ of $\mathrm{FW}$. In total $\mathrm{AD}$, solid- 
liquid separation and digestate liquid treatment accounted for $26 \%$ of the produced energy, of which around $19 \%$ was used in the $\mathrm{AD}$ and separation of the digestate into solid and liquid fractions. The lower energy consumption of only $8-17 \%$ of the total energy produced was previously reported for a theoretical AD plant treating FW (90 $\mathrm{kt} / \mathrm{y}$ ) combined with ammonia stripping and hydrogen recovery, where the additional energy input from the assumed produced hydrogen most likely lowered the ratio between energy input and output (Babson et al., 2013). Compared with the present study, similar energy demand, $17 \%$ and $20 \%$ of the total energy production, was previously assumed in life cycle assessment studies for ADs combined with digestate solid-liquid separation treating 20-60 kt/y of an organic fraction of municipal solid waste and a mixture of municipal and agricultural substrates (Berglund and Börjesson, 2006, Pöschl et al., 2010, respectively). In the present study the differences in the total energy produced in $\mathrm{AD}$ and the lower ratio between energy demand and total energy production compared with a study by Berglund and Börjesson (2006) were due to the high energy content of the FW feedstock in the present study $\left(450 \mathrm{~m}^{3} \mathrm{CH}_{4} / \mathrm{tVS}\right.$ compared to around $300 \mathrm{~m}^{3} \mathrm{CH}_{4} / \mathrm{tVS}$ in Berglund and Börjesson, 2006). If similar digestate liquid treatment systems as those studied in this paper would be applied to an AD plant treating solely, e.g., manure, which produces less methane and has lower VS content (cow manure $148 \mathrm{~m}^{3} \mathrm{CH}_{4} / \mathrm{tVS}$, VS 11\%, Møller et al., 2004), the total energy production of the plant would be lower $(9800 \mathrm{MWh} / \mathrm{y})$ and digestate treatment (solids separation and liquid treatment) would require all of the feedstock's energy and the energy balance would be negative (900 MWh/y needed in addition to the AD plant's energy production). In this sense, the digestate liquid treatment systems are more 
rational options when feedstock has a high methane potential and initial organic matter and nutrient concentrations, such as FW.

Heat consumption of all the studied digestate liquid treatments accounted for 80 $90 \%$ of the total energy demand, because with both stripping and evaporation increased process temperature $\left(80{ }^{\circ} \mathrm{C}\right.$ applied in this study) is needed to achieve efficient nutrient recovery (Mehta et al., 2015). As the electricity consumption between stripping and evaporation was similar (390-400 MWh/y), the total energy consumption was 4100 $\mathrm{kWh} / \mathrm{y}$ with both stripping and evaporation, while the RO treatment consumed only electricity (150-180 MWh/y) as no heat was required. Similarly, evaporation treatment was reported to consume over 50\% more energy compared with the treatment with combined microfiltration, reverse osmosis and ion exchange when digestate originated from a mixture of manure and plant materials $\left(\mathrm{AD}\right.$ with the electric power of $186 \mathrm{~kW}_{\mathrm{el}}$, Rehl and Müller, 2011). Accordingly, due to the large heat demand of digestate liquid treatments with stripping and evaporation, the use of these treatments is rationalized by integration with $\mathrm{AD}$, which enables the recovery of the plant's excess heat (Bonmatí et al., 2003, Fuchs and Drosg, 2013, Hjorth et al., 2010, Mehta et al., 2015), especially in situations where the AD plant's heat energy is not utilized in, e.g., district heating systems.

The results showed that the nitrogen recovery from the digestate liquid treatments consumed $150-210 \mathrm{kWh} / \mathrm{kgN}$, as the consumption was allocated to the recovered nitrogen in the concentrated fertilizer products. This is over 15 times more than the energy consumption of mineral nitrogen fertilizer production in Europe $\left(35.2 \mathrm{GJ} / \mathrm{tNH}_{3} \sim\right.$ $9.8 \mathrm{kWh} / \mathrm{kgNH}_{3}$, Yara, 2015a). However, despite the higher energy consumption of the treatment of digestate liquids, the advantage with the use of liquid fertilizers from waste 
materials is the promotion of nutrient recycling and mitigation of greenhouse gas emissions through anaerobic digestion compared to the manufacturing of mineral fertilizers (Evangelisti et al., 2014). The energy demand in all four digestate liquid treatments combining two to three treatment technologies was also higher compared to a pilot-scale stripping treatment with urine $(18.8-28.2 \mathrm{kWh} / \mathrm{kgN}$ recovered, Antonini et al., 2011), where the lower treatment temperature $\left(40{ }^{\circ} \mathrm{C}\right.$ vs. $80{ }^{\circ} \mathrm{C}$ in the present study) decreased energy consumption. Lower energy consumption was also reviewed with ion exchange, membrane distillation and chemical precipitation technologies $(0.04-0.63$ $\mathrm{kWh} / \mathrm{kgNH}_{3}$, Zarebska et al., 2015), where the treatments did not require heat energy for nutrient recovery. The energy consumption of the studied digestate liquid treatment technologies could be, however, reduced by using lower process temperatures. For example successful ammonia stripping ( $\mathrm{N}$ recovery $>80 \%$ ) has also been reported at temperatures from 35 to $50{ }^{\circ} \mathrm{C}$ (Antonini et al., 2011, Laureni et al., 2013, Liu et al., 2015), while the use of lower temperatures $\left(35-40{ }^{\circ} \mathrm{C}\right)$ with evaporation is possible with the increase of vacuum (pressure 5-7 bars, Bonmatí and Flotats, 2003b, Chiumenti et al., 2013). Additionally, the heat consumption of the treatment processes could be reduced by using heat exchangers to recycle the process heat, which was not taken into consideration in this study.

As the energy consumption during transportation was affected by the mass of fertilizer products (from 16 to $87 \mathrm{kt} / \mathrm{y}$ ), up to an $80 \%$ decrease in the energy consumption during transportation of the fertilizer products was possible using the studied digestate liquid treatment systems when compared to the transportation of the untreated digestate liquid. Energy savings of $80 \%, 67 \%$ and $59 \%$ during transportation were possible with the following treatment systems, respectively: evaporation combined 
with RO (S3); combined stripping, evaporation and RO (S4); stripping combined with RO (S2). This was due to the lower transportable mass compared with the untreated digestate liquid in the reference system (S0). Decreased energy consumption of transportation supports the use of these digestate liquid treatments in $\mathrm{AD}$ plants treating FW, which are usually located far from agricultural lands (Babson et al., 2013) and where the reuse of the FW nutrients is challenging due to long transportation distances. Similar energy savings from transportation of municipal waste-based digestate have been reported after solid-liquid separation, where the energy consumption of transportation of solid digestate after separation decreased $50 \%$ (distance $5 \mathrm{~km}$, Pöschl et al., 2010), thus the transportation of the liquid digestate was not discussed. The advantage with the digestate liquid treatment systems applying RO treatment is the reduction of the total mass of the transportable products compared with the untreated digestate liquid, as some mass exits the system as treated water and retentate. With stripping only (S1), where no RO was included in treatment of digestate liquid, the mass of ammonia sulfate was low, but with the stripping residue also aimed for use in agriculture, the total mass of products was high $(87 \mathrm{kt} / \mathrm{y})$, which is feasible to transport only by minimizing the distance between the AD plant and the fields to be fertilized. A high total mass of $87 \mathrm{kt} / \mathrm{y}$ with stripping (S1) was due to the addition of chemicals during stripping which also led to $10 \%$ higher energy consumption during transportation compared to the reference system (S0).

\subsection{Characteristics of fertilizer products}

The results, based on typical literature values, showed that liquid digestate treatment with evaporation, combined with RO (S3), produced the most concentrated nutrient product by concentrating the original FW mass of $60 \mathrm{kt} / \mathrm{y}$ into $16 \mathrm{kt} / \mathrm{y}$. The high 
nitrogen and potassium and low phosphorus concentrations within the concentrate (18 $\left.\mathrm{kgN} / \mathrm{tFM}, 12 \mathrm{kgNH}_{4}-\mathrm{N} / \mathrm{tFM}, 0.3 \mathrm{kgP} / \mathrm{tFM}, 9 \mathrm{kgK} / \mathrm{tFM}\right)$ compared with the untreated digestate liquid (4 kgN/tFM, $2.7 \mathrm{kgNH}_{4}-\mathrm{N} / \mathrm{tFM}, 0.1 \mathrm{kgP} / \mathrm{tFM}, 1.8 \mathrm{kgK} / \mathrm{tFM}$ ), were dependent on the mass and nutrient recovery and characteristics of the feedstock. Previously similar (18.7 $\mathrm{kgN} / \mathrm{tFM})$ and slightly higher (>20 $\mathrm{kgN} / \mathrm{tFM})$ nitrogen concentrations have been reported after acid evaporation with pig slurry digestate (Chiumenti et al., 2013, Bonmatí and Flotats, 2003b, respectively). Compared with the concentrate from evaporation, commercial mineral fertilizers in solid form have remarkably higher nutrient concentrations (e.g. $303 \mathrm{kgN} / \mathrm{tFM}, 114 \mathrm{kgP} / \mathrm{tFM}, 245$ $\mathrm{kgK} / \mathrm{tFM}$, Abubaker et al., 2012, $266 \mathrm{kgN} / \mathrm{tFM}, 13 \mathrm{kgP} / \mathrm{tFM}, 43 \mathrm{kgK} / \mathrm{tFM}$, Yara, 2015b), thus, the characteristics of $\mathrm{N}$ and $\mathrm{K}$ were in line with commercial liquid fertilizers intended for, e.g., vegetables fertilization $(24 \mathrm{kgN} / \mathrm{tFM}, 55 \mathrm{kgP} / \mathrm{tFM}, 40$ $\mathrm{kgK} / \mathrm{tFM}$, Yara, 2015c). Hence, the concentrate from evaporation could potentially replace liquid mineral fertilizers, especially in cases where phosphorus fertilization is not needed.

All four studied digestate liquid treatment systems produced fertilizer products containing either $\mathrm{N}$ (ammonium sulfate) or $\mathrm{N}, \mathrm{P}$ and $\mathrm{K}$ (concentrate, retentate, stripping residue) in different proportions, which affect their use as fertilizers in agriculture and also affect the amount of fertilizers spread on agricultural lands. The proportion of mineral nitrogen in total $\mathrm{N}\left(\mathrm{NH}_{4}-\mathrm{N} / \mathrm{Ntot}\right)$ was $100 \%$ in the ammonium sulfate from stripping (S1, S2, S4) and 68\% in the concentrate from evaporation (S3), indicating the high availability of $\mathrm{N}$ to plants and fast growth response after fertilization (Abubaker et al., 2012). In concentrate from combined stripping, evaporation and RO (S4), retentate from stripping and $\mathrm{RO}(\mathrm{S} 2)$ and stripping residue from stripping alone (S1) the $\mathrm{NH}_{4}$ - 
N/Ntot was $10 \%, 9 \%$ and $7 \%$, respectively, indicating slower $\mathrm{N}$ release in soils. When considering the NPK ratios, potassium was the dominant nutrient in all fertilizer products (except ammonium sulfate), as the NPK ratios (per FM) were around 100:5:130 in the stripping residue from stripping (S1), the retentate from stripping combined with RO (S2) and the concentrate from combined stripping, evaporation and RO (S4). The concentrate from the system combining evaporation and RO (S3) showed the most balanced NPK ratio of 100:2:50, which was also somewhat similar to the NPK need of herbaceous plants, 100:14:68 (Knecht and Göransson, 2004), thus with remarkably lower $\mathrm{P}$ content. The low share of phosphorus was due to the digestate solid-liquid separation, which distributed only $10 \%$ of the $\mathrm{P}$ in $\mathrm{FW}$ into the liquid digestate, while the water-soluble $\mathrm{N}$ and $\mathrm{K}$ were the predominant nutrients. As follows, all the studied fertilizer products can be used in agriculture supplementing especially $\mathrm{N}$ or $\mathrm{N}$ and $\mathrm{K}$ fertilization in situations where the soil $\mathrm{P}$ content is already high.

The low nutrient concentration within especially stripping residue (from stripping, $\left.\mathrm{S} 1,1.5 \mathrm{kgN} / \mathrm{tFM}, 0.1 \mathrm{kgNH}_{4}-\mathrm{N} / \mathrm{tFM}, 0.1 \mathrm{kgP} / \mathrm{tFM}, 1.9 \mathrm{kgK} / \mathrm{tFM}\right)$ increases the fertilizer application amounts per hectare and discourages the use of the residue in agriculture. The amount of the stripping residue to be spread during fertilization (assumed $\mathrm{N}$ fertilization rate $170 \mathrm{kgN} / \mathrm{ha}$ ) was high, over $100 \mathrm{t} / \mathrm{ha}$, due to the low nutrient concentrations, which could affect the soil properties due to soil wetting/water logging (Rigby and Smith, 2011). More practical volumes were achieved with fertilizer products from other treatment systems, as the amount of mass applied to soils was $4 \mathrm{t} / \mathrm{ha}$ for ammonium sulfate from stripping (S1, S2, S4), 9 t/ha for concentrate from evaporation and $\mathrm{RO}(\mathrm{S} 3)$ and around 25-30 t/ha for concentrate from stripping, evaporation and RO (S4) and retentate from stripping and $\mathrm{RO}(\mathrm{S} 2)$. 
All in all, the most suitable digestate liquid treatment system for concentrated fertilizer products considering nutrients, energy and transportability was the concentrate from the system with evaporation and RO (S3), thus, the production of a different fertilizer product (e.g. ammonium sulfate) is possible with slightly larger energy input with a system combining stripping, evaporation and RO (S4) or stripping and RO (S2). However, along with the recovery of useful nutrients the evaporation and also RO treatment are able to concentrate some undesired components, such as heavy metals, into the concentrate, which could affect the fertilizer use of the products (Mehta et al., 2015). Furthermore, the addition of chemicals to the digestate liquid during the treatment, and their effects on soil after fertilization, should be noticed. E.g. sulfuric acid additions during/after stripping (S1, S2, S4) and before evaporation (S3, S4), both lower the $\mathrm{pH}$ value and increase the salinity, which are likely to cause corrosion (Vaneeckhaute et al., 2013b). Like sulfur, also sodium acts as micronutrient in plant nutrition. However, in large doses sodium increases the soil salinity and affects the soil structure (reviewed in Kronzucker et al., 2013, Veneeckhaute et al., 2013a). The Na concentration in the stripping residue from system S1 was calculated to be around 6 $\mathrm{g} / \mathrm{kgFM}$ which is about double the amount of $\mathrm{Na}$ in manure and manure based digestate (Vaneeckhaute et al., 2013a,b). It is thus important to measure the $\mathrm{pH}$ and salinity of the produced liquid fertilizer products and monitor the effect of these products in soils after fertilization.

\section{Conclusions}

This theoretical study showed the feasibility of FW nutrient recovery through AD and digestate liquid treatment and the production of transportable fertilizer products with the energy produced in AD. Despite the use of heat-demanding treatments, such as 
evaporation and stripping, the energy produced in AD was sufficient for digestate liquid treatment consuming fewer than $10 \%$ of the total energy produced in $\mathrm{AD}$. The studied digestate liquid treatment systems were mostly considered as nitrogen concentration methods which are able to concentrate up to $67 \%$ of feedstock nitrogen into liquid fertilizer products with low mass. Of the studied digestate systems evaporation combined with RO was evaluated as the most efficient nutrient recovery technology for the production of transportable fertilizer products for agricultural application due to the highest concentration of nutrients, nutrient availability, the low mass of the product and low energy consumption of the treatment. Stripping was an efficient technology for the recovery of nitrogen, however, the high mass of the residue containing the remaining $\mathrm{K}$ and $\mathrm{P}$ should be further managed sustainably. Overall, the selection of the treatment technology is dependent on the location of the $\mathrm{AD}$ plant relative to agricultural lands and the type of fertilizer products needed ( $\mathrm{N}$ fertilizer, NPK fertilizer).

\section{Acknowledgements}

This work was funded by the Fortum Foundation (grant number 201400302). The authors are grateful to Karetta Timonen, Taija Sinkko, Sari Luostarinen, Juha Grönroos, Kaisa Manninen, Teija Paavola and Erkka Laine for the valuable comments and advice during a project that preceded this work. 


\section{References}

Abubaker, J., Risberg, K., Pell, M., 2012. Biogas residues as fertilisers - Effect on wheat growth and soil microbial activities. Appl Energ 99, 126-134. http://dx.doi.org/10.1016/j.apenergy.2012.04.050

Alvarenga, E., Hayrapetyan, S., Govasmark, E., Hayrapetyan, L., Salbu, B., 2015. Study of the flocculation of anaerobically digested residue and filtration properties of bentonite based mineral conditioners. J Environ Chem Eng 3, 1399-1407. http://dx.doi.org/10.1016/j.jece.2015.01.015

Antonini, S., Paris, S., Eichert, T., Clemens, J., 2011. Nitrogen and phosphorus recovery from human urine by struvite precipitation and air stripping in Vietnam. Clean -Soil Air Water 39, 1099-1104. http://dx.doi.org/10.1002/clen.201100036

Babson, D.M., Bellman, K., Prakash, S., Fennell, D.E., 2013. Anaerobic digestion for methane generation and ammonia reforming for hydrogen production: A thermodynamic energy balance of a model system to demonstrate net energy feasibility. Biomass Bioenerg 56, 493-505. http://dx.doi.org/10.1016/j.biombioe.2013.05.024

Bacenetti, J., Negri, M., Fiala, M., González-García, S., 2013. Anaerobic digestion of different feedstocks: Impact on energetic and environmental balances of biogas process. Sci Total Environ 463-464, 541-551. http://dx.doi.org/10.1016/j.scitotenv.2013.06.058

Banks, C., Chessire, M., Heaven, S., Arnold, R., 2011. Anaerobic digestion of source-segregated domestic food waste: Performance assessment by mass and energy balance. Bioresour Technol 102, 612-620. http://dx.doi.org/10.1016/j.biortech.2010.08.005 
Basakcilardan-Kabakci, S., Ipekoglu, A.N., Talini, I., 2007. Recovery of ammonia from human urine by stripping and absorption. Environ Eng Sci 24, 615-624. http://dx.doi.org/10.1089/ees.2006.0412

Berglund, M., Börjesson, P., 2006. Assessment of energy performance in the lifecycle of biogas production. Biomass Bioenerg 30, 254-266. http://dx.doi.org/10.1016/j.biombioe.2005.11.011

Boehler, M.A., Heisele, A. Seyfried, A., Grömping, M., Siegrist, H., 2015. $\left(\mathrm{NH}_{4}\right)_{2} \mathrm{SO}_{4}$ recovery from liquid side streams. Environ Sci Pollut Res 22, 7295-7305. http://dx.doi.org/10.1007/s11356-014-3392-8

Bonmatí, A., Flotats, X., 2003a. Air stripping of ammonia from pig slurry: characterization and feasibility as a pre- or post-treatment to mesophilic anaerobic digestion. Waste Manage 23, 261-272. http://dx.doi.org/10.1016/S0956053X(02)00144-7

Bonmatí, A., Flotats, X., 2003b. Pig slurry concentration by vacuum evaporation: influence of previous mesophilic anaerobic digestion process. J Air \& Waste Manage Assoc 53, 21-31. http://dx.doi.org/10.1080/10473289.2003.10466112

Bonmatí, A., Campos, E., Flotats, X. 2003. Concentration of pig slurry by evaporation: anaerobic digestion as the key process. Water Sci Technol 48, 189-194.

Camilleri-Rumbau, M.S., Norddahl, B., Wei, J., Christensen, K.V., Søtoft, L.F., 2014. Microfiltration and ultrafiltration as a post-treatment of biogas plant digestates for producing concentrated fertilizers. Desalin Water Treat 12, 1-15. http://dx.doi.org/10.1080/19443994.2014.989638 
Carretier, S., Lesage, G., Grasmick, A., Heran, M., 2015. Water and nutrients removing from livestock manure by membrane processes. Can J Chem Eng 93, 225233. http://dx.doi.org/10.1002/cjce. 22125

Chiumenti, R., Chiumenti, A., da Borso, F., 2010. Digestate treatment by means of a full scale membrane system: an innovative method for managing surplus nitrogen and for valorizing farm effluents. Ramiran 2010, $14^{\text {th }}$ Ramiran International Conference, Lisbon, Portugal, 12-15 September, 2010.

Chiumenti, A., da Borso, F., Chiumenti, R., Teri, F., Segantin, P., 2013. Treatment of digestate from a co-digestion biogas plant by means of vacuum evaporation: Tests for process optimization and environmental sustainability. Waste Manage 33, 1339-1344. http://dx.doi.org/10.1016/j.wasman.2013.02.023

Ek, M., Bergström, R., Bjurhem, J.-E., Björlenius, B., Hellström, D., 2006. Concentration of nutrients from urine and reject water from anaerobically digested sludge. Water Sci Technol 54, 437-444. http://dx.doi.org/10.2166/wst.2006.924

Ervasti, S., Paavola, T., Rintala, J., 2011. Recovery of nitrogen and phosphorus from biogas plant digestate with combined ammonia stripping and water evaporation. International IWA-Symposium on Anaerobic Digestion of Solid Waste and Energy Crops, August 28-September 01, 2011, Vienna, Austria.

European Council, 2011. Commission Regulation (EU) No 142/2011 of 25 February 2011 implementing Regulation (EC) No 1069/2009 of the European Parliament and of the Council laying down health rules as regards animal by-products and derived products not intended for human consumption and implementing Council Directive 97/78/EC as regards certain samples and items exempt from veterinary checks 
at the border under that Directive. Official Journal of the European Union L 054, 26/02/2011, pp. 0001-0254.

European Parliament and the Council, 2009. Regulation (EC) No 1069/2009 of the European Parliament and of the Council of 21 October 2009 laying down health rules as regards animal by-products and derived products not intended for human consumption and repealing Regulation (EC) No 1774/2002 (Animal by-products Regulation). Official Journal of the European Union L 300, 14/11/2009, pp. 0001-0033.

Evangelisti, S., Lettieri, P., Borello, D., Clift, R., 2014. Life cycle assessment of energy from waste via anaerobic digestion: A UK case study. Waste Manage 34, 226237. http://dx.doi.org/10.1016/j.wasman.2013.09.013

Flotats, X., Foged, H.L., Bonmati Blasi, A., Palatsi, J., Magri, A., Schelde, K.M., 2011. Manure processing technologies. Technical Report No. II concerning "Manure Processing Activities in Europe" to the European Commission, Directorate-General Environment. 184 pp. Available at http://agro-technologyatlas.eu/docs/21010_technical_report_II_manure_processing_technologies.pdf [accessed on 11.06.2015]

Fuchs, W., Drosg, B. 2013. Assessment of the state of the art of technologies for the processing of digestate residue from anaerobic digesters. Water Sci Technol 67, 1984-1993. http://dx.doi.org/10.2166/wst.2013.075

Guštin, S., Marinšek-Logar, R., 2011. Effect of pH, temperature and air flow rate on the continuous ammonia stripping of the anaerobic digestion effluent. Process Saf Environ 89, 61-66. http://dx.doi.org/10.1016/j.psep.2010.11.001 
Havukainen, J., Uusitalo, V., Niskanen, A., Kapustina, V., Horttanainen, M., 2014. Evaluation of methods for estimating energy performance of biogas production. Renew Energ 66, 232-240. http://dx.doi.org/10.1016/j.renene.2013.12.011

Hjorth, M., Christensen, K.V., Christensen, M.L., Sommer, S.G., 2010. Solidliquid separation of animal slurry in theory and practice. A review. Agron Sustain Dev 30, 153-180. http://dx.doi.org/10.1007/978-94-007-0394-0_43

Karellas, S., Boukis, I., Kontopoulos, G., 2010. Development of an investment decision tool for biogas production from agricultural waste. Renew Sust Energ Rev 14, 1273-1282. http://dx.doi.org/10.1016/j.rser.2009.12.002

Knecht, M.F., Göransson, A., 2004. Terrestrial plants require nutrients in similar proportions. Tree Physiol 24, 447-460. http://dx.doi.org/10.1093/treephys/24.4.447

Kronzucker, H.J., Coskun, D., Schulze, L.M., Wong, J.R., Britto, D.T. 2013. Sodium as nutrient and toxicant. Plant Soil 369, 1-23. http://dx.doi.org/10.1007/s11104$013-1801-2$

Laureni, M., Palatsi, J., Llovera, M., Bonmatí, A., 2013. Influence of pig slurry characteristics on ammonia stripping efficiencies and quality of the recovered ammonium-sulfate solution. J Chem Technol Biotechnol 88, 1654-1662. http://dx.doi.org/10.1002/jctb.4016

Ledda, C., Schievano, A., Salati, S., Adani, F., 2013. Nitrogen and water recovery from animal slurries by a new integrated ultrafiltration, reverse osmosis and cold stripping process: A case study. Water Res 47, 6165-6166.

http://dx.doi.org/10.1016/j.watres.2013.07.037 
Liu, L., Pang, C., Wu, S., Dong, R., 2015. Optimization and evaluation of airrecirculated stripping for ammonia removal from the anaerobic digestate of pig manure. Process Saf Environ 94, 350-357. http://dx.doi.org/10.1016/j.psep.2014.08.006

Mehta, C.M., Khunjar, W.O., Nguyen, V., Tait, S., Batstone, D.J., 2015. Technologies to recover nutrients from waste streams: A critical review. Crit Rev Env Sci Tec 45, 385-427. http://dx.doi.org/10.1080/10643389.2013.866621

Mauer, M., Schwegler, P., Larsen, T.A., 2003. Nutrients in urine: energetic aspect of removal and recovery. Water Sci Technol 48, 37-46.

Mondor, M., Masse, L., Ippersiel, D., Lamarche, F., Massé, D.I., 2008. Use of electrodialysis and reverse osmosis for the recovery and concentration of ammonia from swine manure. Bioresour Technol 99, 7363-7368. http://dx.doi.org/10.1016/j.biortech.2006.12.039

Møller, H.B., Lund, I., Sommer, S.G., 2000. Solid-liquid separation of livestock slurry: efficiency and cost. Bioresour Technol 74, 223-229. http://dx.doi.org/10.1016/S0960-8524(00)00016-X

Møller, H.B., Sommer, S.G., Ahring, B.K., 2002. Separation efficiency and particle size distribution in relation to manure type and storage conditions. Bioresour Technol 85, 189-196. http://dx.doi.org/10.1016/S0960-8524(02)00047-0

Møller, H.B., Sommer, S.G., Ahring, B.K., 2004. Methane productivity of manure, straw and solid fractions of manure. Biomass Bioenerg 26, 485-495. http://dx.doi.org/ 10.1016/j.biombioe.2003.08.008

Naegele, H.J., Lemmer, A., Oechsner, H., Jungbluth, T. 2012. Electric energy consumption of the full scale research biogas plant "Unterer Lindenhof": Results of 
longterm and full detail measurements. Energies 5, 5198-5214.

http://dx.doi.org/10.3390/en5125198

Poeschl, M., Ward, S., Owende, P., 2012. Environmental impacts of biogas deployment - Part I: life cycle inventory for evaluation of production process emissions to air. J Clean Prod 24, 168-183. http://dx.doi.org/10.1016/j.jclepro.2011.10.039

Prapaspongsa, T., Poulsen, T.G., Hansen, J.A., Christensen, P., 2010. Energy production, nutrient recovery and greenhouse gas emission potentials from integrated pig manure management systems. Waste Manage Res 28, 411-422. http://dx.doi.org/10.1177/0734242X09338728

Pöschl, M., Ward, S., Owende, P., 2010. Evaluation of energy efficiency of various biogas production and utilization pathways. Appl Energ 87, 3305-3321. http://dx.doi.org/10.1016/j.apenergy.2010.05.011

Rapport, J.L., Zhang, R., Jenkins, B.M., Hartsough, B.R., Tomich, T.P., 2011. Modeling the performance of the anaerobic phased solids digester system for biogas energy production. Biomass Bioenerg 35, 1263-1272. http://dx.doi.org/10.1016/j.biombioe.2010.12.021

Rehl, T., Müller, J., 2011. Life cycle assessment of biogas digestate processing technologies. Resour Conserv Recy 56, 92-104. http://dx.doi.org/10.1016/j.resconrec.2011.08.007

Rigby, H., Smith, S.R., 2011. New markets for digestate from anaerobic digestion. Desktop study on new markets. Wrap, Material change for a better environment. Aug 2011. Available at: 
http://www.wrap.org.uk/sites/files/wrap/New_Markets_for_AD_WRAP_format_Final_ v2.c6779ccd.11341.pdf [accessed on 25.6.2015]

Saveyn, H., Eder, P., 2014. End-of-waste criteria for biodegradable waste subjected to biological treatment (Compost \& Digestate): Technical proposals. JRC Scientific and Policy Reports. European Commission, Joint Research Centre, Institute for Prospective Technological Studies. EUR 26425 EN.

Smyth, B.M., Murphy, J.D., O’Brien, C.M., 2009. What is the energy balance of grass biomethane in Ireland and other temperate northern European climates? Renew Sust Energ Rev 13, 2349-2360. http://dx.doi.org/10.1016/j.rser.2009.04.003

Sørensen, P., Eriksen, J., 2009. Effects of slurry acidification with sulphuric acid combined with aeration on the turnover and plant availability of nitrogen. Agr Ecosyst Environ 131, 240-246. http://dx.doi.org/10.1016/j.agee.2009.01.024

Tampio, E., Ervasti, S., Paavola, T., Heaven, S., Banks, C., Rintala, J., 2014. Anaerobic digestion of untreated and autoclaved food waste. Waste Manage 34, 370377. http://dx.doi.org/10.1016/j.wasman.2013.10.024

Tampio, E., Ervasti, S., Rintala, J., 2015. Characteristics and agronomic usability of digestates from laboratory digesters treating food waste and autoclaved food waste. $\mathbf{J}$ Clean Prod 94, 86-92. http://dx.doi.org/10.1016/j.jclepro.2015.01.086

Vaneeckhaute, C., Meers, E., Michels, E., Ghkiere, G., Accoe, F., Tack, F.M.G. 2013a. Closing the nutrient cycle by using bio-digestion waste derivates as synthetic fertilizer substitutes: A field experiment. Biomass Bioenerg 55, 175-189. http://dx.doi.org/10.1016/j.biombioe.2013.01.032 
Vaneeckhaute, C., Meers, E., Michels, E, Buysse, J., Tack, F.M.G. 2013 b.

Ecological and economic benefits of the application of bio-based mineral fertilizers in modern agriculture. Biomass Bioenerg 49, 239-248.

http://dx.doi.org/10.1016/j.biombioe.2012.12.036

van Eekert, M., Weijma, J., Verdoes, N., de Buisonjé, F., Reitsma, B., van der Bulk, J., van Gastel, J., 2012. Explorative research on innovative nitrogen recovery. Rapport 51, 2012. STOWA. Available at: http://www.stowa.nl/Upload/publicaties/STOWA\%202012\%2051_LR.pdf [accessed on 25.6.2015]

VTT, 2012. LIPASTO -emission calculation system, VTT Technical Research Centre of Finland. Available at: http://lipasto.vtt.fi/yksikkopaastot/tavaraliikennee/tieliikennee/tavara_tiee.htm [accessed on 8.7.2015]

Yara, 2015a. Life Cycle Analysis of Ammonium Nitrate. Available at: http://www.yara.fi/lannoitus/ymparisto/reducing-carbon-footprint/fertilizer-life-cycleperspective/life-cycle-analysis-of-ammonium-nitrate/ [accessed on 7.9.2015]

Yara, 2015b. YaraMila Y 1 (in Finnish). Available at: http://www.yara.fi/lannoitus/tuotteet/yaramila/18b0-yaramila-y-1/ [accessed on 7.9.2015]

Yara, 2015c. Ferticare starttiliuos (in Finnish). Available at: http://www.yara.fi/lannoitus/tuotteet/other/1883-ferticare-starttiliuos/ [accessed on 7.9.2015] 
Zarebska, A., Nieto, D.R., Christensen, K.V., Søtoft, L.F., Norddahl, B., 2015. Ammonium fertilizers production from manure: A critical review. Crit Rev Env Sci Tec 45, 1469-1521. http://dx.doi.org/10.1080/10643389.2014.955630 
Table 1. The separation efficiency of decanter centrifuge, nutrient recovery efficiencies of digestate liquid treatment technologies and energy consumption of each treatment. Values chosen based on literature (see also Supplementary material).

\begin{tabular}{|c|c|c|c|c|c|c|c|c|}
\hline \multirow[t]{2}{*}{ Material } & \multicolumn{7}{|c|}{ Separation/recovery efficiency, $\%$} & \multirow{2}{*}{$\begin{array}{l}\text { Energy } \\
\text { consumption, } \\
\text { kWh/t to be treated }\end{array}$} \\
\hline & Mass & TS & VS & Ntot & $\mathrm{NH}_{4}-\mathrm{N}$ & Ptot & Ktot & \\
\hline \multicolumn{9}{|c|}{ Solid-liquid separation of digestate } \\
\hline Liquid digestate & $90^{\mathrm{a}}$ & $20^{\mathrm{a}}$ & $20^{\mathrm{b}}$ & $70^{\mathrm{a}}$ & $81^{\mathrm{a}}$ & $10^{\mathrm{a}}$ & $85^{\mathrm{a}}$ & $3.5^{\mathrm{a}}$ \\
\hline \multicolumn{9}{|c|}{$\begin{array}{l}\text { Digestate liquid treatment } \\
\text { Strinning }\end{array}$} \\
\hline Ammonium sulfate & - & - & - & - & $95^{\mathrm{c}}$ & - & - & $2^{\mathrm{d}}+$ heat $^{\mathrm{e}}$ \\
\hline Evaporation & & & & & & & & \\
\hline Concentrate & $20^{\mathrm{f}}$ & - & - & $90^{f}$ & - & $100^{\mathrm{f}}$ & $100^{\mathrm{f}}$ & $5^{\mathrm{f}}+$ heat $^{\mathrm{e}}$ \\
\hline Reverse osmosis & & & & & & & & \\
\hline Rententate & $28^{\mathrm{g}}$ & $100^{\mathrm{g}}$ & $100^{\mathrm{g}}$ & - & $95^{\mathrm{g}}$ & $95^{\mathrm{g}}$ & $99^{\mathrm{g}}$ & $2.5^{\mathrm{g}}$ \\
\hline
\end{tabular}

${ }^{a}$ Flotats et al., 2011, reviewed in Hjorth et al., 2010, Ledda et al., 2013, Møller et al., 2000, 2002

${ }^{\mathrm{b}}$ Separation efficiency for VS was assumed to be same as for TS

${ }^{c}$ Basakcilardan-Kabakci et al., 2007, Bonmatí and Flotats, 2003a, Flotats et al., 2011, Guštin and Marinšek-Logar, 2011, Laureni et al., 2013, Liu et al., 2015

${ }^{\mathrm{d}} \mathrm{kWh} / \mathrm{kgN}$ recovered in ammonium sulfate, reviewed in van Eekert et al., 2012

${ }^{\mathrm{e}} \mathrm{Calculated}$ with the specific heat capacity of water

${ }^{\mathrm{f}}$ Bonmatí and Flotats, 2003b, Chiumenti et al., 2013, Ek et al., 2006, Flotats et al., 2011, Mauer et al., 2003

${ }^{g}$ Carretier et al., 2015, Chiumenti et al., 2010, Ek et al., 2006, Flotats et al., 2011, Ledda et al., 2013, Mondor et al., 2008

-, not applicable 
Table 2. Mass and nutrient flows presented as tonnes per year ( $\mathrm{t} / \mathrm{y})$, and concentrations ( $\mathrm{kg} / \mathrm{tFM}$, in parentheses) in feedstock, digestate, separated solid and liquid digestate fractions and outputs of the digestate liquid treatment systems ( $\mathrm{S} 0-\mathrm{S} 4)$. Fresh matter (FM), reverse osmosis (RO).

\begin{tabular}{|c|c|c|c|c|c|c|c|}
\hline Material & Mass & TS & VS & Ntot & $\mathrm{NH}_{4}-\mathrm{N}$ & Ptot & Ktot \\
\hline \multicolumn{8}{|l|}{ Reactor feedstock } \\
\hline Food waste & 60000 & $\begin{array}{l}15000 \\
(250.0)\end{array}$ & $\begin{array}{l}13800 \\
(230.0)\end{array}$ & $\begin{array}{l}450 \\
(7.5)\end{array}$ & $\begin{array}{l}24 \\
(0.4)\end{array}$ & $\begin{array}{l}54 \\
(0.9)\end{array}$ & $\begin{array}{l}168 \\
(2.8)\end{array}$ \\
\hline $\begin{array}{l}\text { Dilution water (recycled water in } \\
\text { S3-S4) }\end{array}$ & 40000 & - & - & - & - & - & - \\
\hline \multicolumn{8}{|c|}{ Biogas, digestate and solid-liquid separation } \\
\hline Biogas & 12586 & 12586 & 12586 & - & - & - & - \\
\hline Digestate & 87414 & 2414 & 1214 & 450 & 264 & 54 & 168 \\
\hline Liquid digestate, $\mathrm{S} 0$ no treatment & 78673 & $\begin{array}{l}483 \\
(6.1)\end{array}$ & $\begin{array}{l}243 \\
(3.1)\end{array}$ & $\begin{array}{l}315 \\
(4.0)\end{array}$ & $\begin{array}{l}214 \\
(2.7)\end{array}$ & $\begin{array}{l}5 \\
(0.1)\end{array}$ & $\begin{array}{l}143 \\
(1.8)\end{array}$ \\
\hline Solid digestate, S0-S4 & 8741 & $\begin{array}{l}1932 \\
(221.0)\end{array}$ & $\begin{array}{l}972 \\
(111.1)\end{array}$ & $\begin{array}{l}135 \\
(15.4)\end{array}$ & $\begin{array}{l}50 \\
(5.7)\end{array}$ & $\begin{array}{l}49 \\
(5.6)\end{array}$ & $\begin{array}{l}25 \\
(2.9)\end{array}$ \\
\hline \multicolumn{8}{|l|}{ Digestate liquid treatment } \\
\hline \multicolumn{8}{|l|}{ Stripping, S1 } \\
\hline Ammonium sulfate & $11373^{\mathrm{a}}$ & & $\begin{array}{l}0 \\
(0)\end{array}$ & $\begin{array}{l}203 \\
(40)\end{array}$ & $\begin{array}{l}203 \\
(40)\end{array}$ & $\begin{array}{l}0 \\
(0)\end{array}$ & $\begin{array}{l}0 \\
(0)\end{array}$ \\
\hline Stripping residue & $73594^{\mathrm{b}}$ & $\begin{array}{l}483 \\
(6.4)\end{array}$ & $\begin{array}{l}243 \\
(3.2)\end{array}$ & $\begin{array}{l}112 \\
(1.5)\end{array}$ & $\begin{array}{l}11 \\
(0.1)\end{array}$ & $\begin{array}{l}5 \\
(0.1)\end{array}$ & $\begin{array}{l}143 \\
(1.9)\end{array}$ \\
\hline \multicolumn{8}{|l|}{ Stripping $+R O, S 2$} \\
\hline Ammonium sulfate & $11373^{\mathrm{a}}$ & $\begin{array}{l}0 \\
(0)\end{array}$ & $\begin{array}{l}0 \\
(0)\end{array}$ & $\begin{array}{l}203 \\
(40)\end{array}$ & $\begin{array}{l}203 \\
(40)\end{array}$ & $\begin{array}{l}0 \\
(0)\end{array}$ & $\begin{array}{l}0 \\
(0)\end{array}$ \\
\hline Stripping residue (to $\mathrm{RO}$ ) & $75168^{\mathrm{b}}$ & $\begin{array}{l}483 \\
(6.4)\end{array}$ & $\begin{array}{l}243 \\
(3.2)\end{array}$ & $\begin{array}{l}112 \\
(1.5)\end{array}$ & $\begin{array}{l}11 \\
(0.1)\end{array}$ & $\begin{array}{l}5 \\
(0.1)\end{array}$ & $\begin{array}{l}143 \\
(1.9)\end{array}$ \\
\hline Retentate & 20606 & $\begin{array}{l}483 \\
(23.4)\end{array}$ & $\begin{array}{l}243 \\
(11.8)\end{array}$ & $\begin{array}{l}111 \\
(5.4)\end{array}$ & $\begin{array}{l}10 \\
(0.5)\end{array}$ & $\begin{array}{l}5 \\
(0.2)\end{array}$ & $\begin{array}{l}141 \\
(6.9)\end{array}$ \\
\hline Processed water (recycled) & 52988 & $\begin{array}{l}0 \\
(0)\end{array}$ & $\begin{array}{l}0 \\
(0)\end{array}$ & $\begin{array}{l}1 \\
(0.01)\end{array}$ & $\begin{array}{l}1 \\
(0.01)\end{array}$ & $\begin{array}{l}0 \\
(0.01)\end{array}$ & $\begin{array}{l}1 \\
(0.03)\end{array}$ \\
\hline \multicolumn{8}{|l|}{ Evaporation $+R O, S 3$} \\
\hline Concentrate & $15820^{\mathrm{c}}$ & $\begin{array}{l}483 \\
(30.5)\end{array}$ & $\begin{array}{l}243 \\
(15.4)\end{array}$ & $\begin{array}{l}284 \\
(17.9)\end{array}$ & $\begin{array}{l}192 \\
(12.2)\end{array}$ & $\begin{array}{l}5 \\
(0.3)\end{array}$ & $\begin{array}{l}143 \\
(9.0)\end{array}$ \\
\hline Condensate (to RO) & 62938 & $\begin{array}{l}0 \\
(0)\end{array}$ & $\begin{array}{l}0 \\
(0)\end{array}$ & $\begin{array}{l}32 \\
(0.5)\end{array}$ & $\begin{array}{l}21 \\
(0.3)\end{array}$ & $\begin{array}{l}0 \\
(0)\end{array}$ & $\begin{array}{l}0 \\
(0)\end{array}$ \\
\hline Retentate (recycled) & 17623 & $\begin{array}{l}0 \\
(0)\end{array}$ & $\begin{array}{l}0 \\
(0)\end{array}$ & $\begin{array}{l}30 \\
(1.7)\end{array}$ & $\begin{array}{l}20 \\
(1.2)\end{array}$ & $\begin{array}{l}0 \\
(0)\end{array}$ & $\begin{array}{l}0 \\
(0)\end{array}$ \\
\hline Processed water (recycled) & 45316 & $\begin{array}{l}0 \\
(0)\end{array}$ & $\begin{array}{l}0 \\
(0)\end{array}$ & $\begin{array}{l}1 \\
(0.02)\end{array}$ & $\begin{array}{l}1 \\
(0.02)\end{array}$ & $\begin{array}{l}0 \\
(0)\end{array}$ & $\begin{array}{l}0 \\
(0)\end{array}$ \\
\hline \multicolumn{8}{|l|}{ Stripping + evaporation $+R O, S 4$} \\
\hline Ammonium sulfate & $11373^{\mathrm{a}}$ & $\begin{array}{l}0 \\
(0)\end{array}$ & $\begin{array}{l}0 \\
(0)\end{array}$ & $\begin{array}{l}203 \\
(40)\end{array}$ & $\begin{array}{l}203 \\
(40)\end{array}$ & $\begin{array}{l}0 \\
(0)\end{array}$ & $\begin{array}{l}0 \\
(0)\end{array}$ \\
\hline Stripping residue (to evaporation) & $73594^{\mathrm{b}}$ & $\begin{array}{l}483 \\
(6.4)\end{array}$ & $\begin{array}{l}243 \\
(3.2)\end{array}$ & $\begin{array}{l}112 \\
(1.5)\end{array}$ & $\begin{array}{l}11 \\
(0.1)\end{array}$ & $\begin{array}{l}5 \\
(0.1)\end{array}$ & $\begin{array}{l}143 \\
(1.9)\end{array}$ \\
\hline Concentrate & $14798^{d}$ & $\begin{array}{l}483 \\
(32.6)\end{array}$ & $\begin{array}{l}243 \\
(16.4)\end{array}$ & $\begin{array}{l}101 \\
(6.8)\end{array}$ & $\begin{array}{l}10 \\
(0.7)\end{array}$ & $\begin{array}{l}5 \\
(0.4)\end{array}$ & $\begin{array}{l}143 \\
(9.6)\end{array}$ \\
\hline Condensate (to RO) & 58875 & $\begin{array}{l}0 \\
(0)\end{array}$ & $\begin{array}{l}0 \\
(0)\end{array}$ & $\begin{array}{l}11 \\
(0.2)\end{array}$ & $\begin{array}{l}1 \\
(0.02)\end{array}$ & $\begin{array}{l}0 \\
(0)\end{array}$ & $\begin{array}{l}0 \\
(0)\end{array}$ \\
\hline Retentate (recycled) & 16485 & $\begin{array}{l}0 \\
(0)\end{array}$ & $\begin{array}{l}0 \\
(0)\end{array}$ & $\begin{array}{l}11 \\
(0.7)\end{array}$ & $\begin{array}{l}1 \\
(0.1)\end{array}$ & $\begin{array}{l}0 \\
(0)\end{array}$ & $\begin{array}{l}0 \\
(0)\end{array}$ \\
\hline Processed water (recycled) & 42390 & $\begin{array}{l}0 \\
(0)\end{array}$ & $\begin{array}{l}0 \\
(0)\end{array}$ & $\begin{array}{l}0 \\
(0.001)\end{array}$ & $\begin{array}{l}0 \\
(0.001)\end{array}$ & $\begin{array}{l}0 \\
(0)\end{array}$ & $\begin{array}{l}0 \\
(0)\end{array}$ \\
\hline
\end{tabular}

${ }^{a} \mathrm{H}_{2} \mathrm{SO}_{4}$ addition of $6293 \mathrm{~m}^{3} / \mathrm{y},{ }^{\mathrm{b}} \mathrm{NaOH}$ addition of $1573 \mathrm{~m}^{3} / \mathrm{y},{ }^{\mathrm{c}} \mathrm{H}_{2} \mathrm{SO}_{4}$ addition of $85 \mathrm{~m}^{3} / \mathrm{y},{ }^{\mathrm{d}} \mathrm{H}_{2} \mathrm{SO}_{4} 80 \mathrm{~m}^{3} / \mathrm{y}$ -, not applicable 
Table 3. The partition of feedstock mass and nutrients in the digestate, separated solid and liquid digestates and fertilizer products from the digestate liquid treatment systems (S0-S4). The partition is presented as \% of the feedstock. The mass is calculated from the feedstock fed to the digester ( $60 \mathrm{kt}$ food waste $+40 \mathrm{kt}$ dilution water). The addition of chemicals is not taken into consideration in the mass partition. Reverse osmosis (RO).

\begin{tabular}{|c|c|c|c|c|c|}
\hline$\%$ of feedstock & Mass & Ntot & $\mathrm{NH}_{4}-\mathrm{N}$ & Ptot & Ktot \\
\hline \multicolumn{6}{|c|}{ Digestate and solid-liquid separation } \\
\hline Digestate & 87 & 100 & 1100 & 100 & 100 \\
\hline Liquid digestate, $\mathrm{S} 0$ & 79 & 70 & 891 & 10 & 85 \\
\hline Solid digestate, S0-S4 & 9 & 30 & 209 & 90 & 15 \\
\hline \multicolumn{6}{|l|}{ Stripping, S1 } \\
\hline Ammonium sulfate & 5 & 45 & 846 & 0 & 0 \\
\hline Stripping residue & 74 & 25 & 45 & 10 & 85 \\
\hline Fertilizer products in total & 79 & 70 & 891 & 10 & 85 \\
\hline \multicolumn{6}{|l|}{ Stripping $+R O, S 2$} \\
\hline Ammonium sulfate & 5 & 45 & 846 & 0 & 0 \\
\hline Retentate & 21 & 25 & 42 & 10 & 84 \\
\hline Fertilizer products in total & 26 & 70 & 888 & 10 & 84 \\
\hline \multicolumn{6}{|l|}{ Evaporation $+R O, S 3$} \\
\hline Concentrate & 16 & 63 & 802 & 10 & 85 \\
\hline \multicolumn{6}{|c|}{ Stripping + evaporation $+R O, S 4$} \\
\hline Ammonium sulfate & 5 & 45 & 846 & 0 & 0 \\
\hline Concentrate & 15 & 22 & 40 & 10 & 85 \\
\hline Fertilizer products in total & 20 & 67 & 886 & 10 & 85 \\
\hline
\end{tabular}


Table 4. Energy production of the studied anaerobic digestion (AD) plant and the energy consumption during AD (including pretreatment and hygienization, biogas upgrading and digester), digestate separation and digestate liquid treatment. Energy consumption of the digestate liquid treatment is calculated towards the recovered concentrated fertilizer fractions (ammonium sulfate, concentrate), where stripping residue from $\mathrm{S} 1$ and retentate from $\mathrm{S} 2$ were not included. Reverse osmosis (RO), combined heat and power (CHP), electricity (el), thermal (th).

\begin{tabular}{llllll}
\hline Process & $\begin{array}{l}\text { Electricity } \\
\left(\mathrm{MWh}_{\mathrm{e}} \mathrm{y}\right)\end{array}$ & $\begin{array}{l}\mathrm{Heat} \\
\left(\mathrm{MWh}_{\mathrm{th}} / \mathrm{y}\right)\end{array}$ & $\begin{array}{l}\text { Total } \\
(\mathrm{MWh} / \mathrm{y})\end{array}$ & $\begin{array}{l}\text { Total } \\
(\mathrm{kWh} / \mathrm{kgN})\end{array}$ & $\begin{array}{l}\text { Electricity } \\
\left(\mathrm{kWh}_{\mathrm{e}} / \mathrm{kgN}\right)\end{array}$ \\
\hline $\begin{array}{l}\text { Energy production } \\
\text { Primary energy production in AD }\end{array}$ & - & - & 62100 & - & - \\
$\begin{array}{l}\text { Energy in CHP } \\
\text { Energy consumption }\end{array}$ & 23598 & 29187 & 52785 & - & - \\
AD & & & & & \\
Solid-liquid separation & 5293 & 6142 & 11435 & - & - \\
Energy consumption in digestate liquid treatment & 306 & - & 306 & - & - \\
No treatment, S0 & 0 & 0 & 0 & & \\
Stripping, S1 & 406 & 3727 & 4133 & 203 & 20 \\
Stripping + RO, S2 & 590 & 3727 & 4317 & 213 & 29 \\
Evaporation + RO, S3 & 551 & 3658 & 4209 & 148 & 19 \\
Stripping + evaporation + RO, S4 & 922 & 3727 & 4649 & 153 & 30 \\
\hline
\end{tabular}

- , not applicable 


\section{Figure Captions}

Figure 1. System boundaries of the studied anaerobic digestion plant and digestate liquid treatment with material and energy flows. Grey boxes represent feedstock/product and white boxes represent studied unit operations.

Figure 2. Digestate liquid treatment systems (S0-S4) and products evaluated in this study. White boxes represent treatments and grey boxed represent treatment inputs and outputs.

Figure 3. Energy consumption of transportation (megawatt hours per year, MWh/y) of fertilizer products produced in each digestate liquid treatment system in relation to the transportation distance. 
Fig. 1.

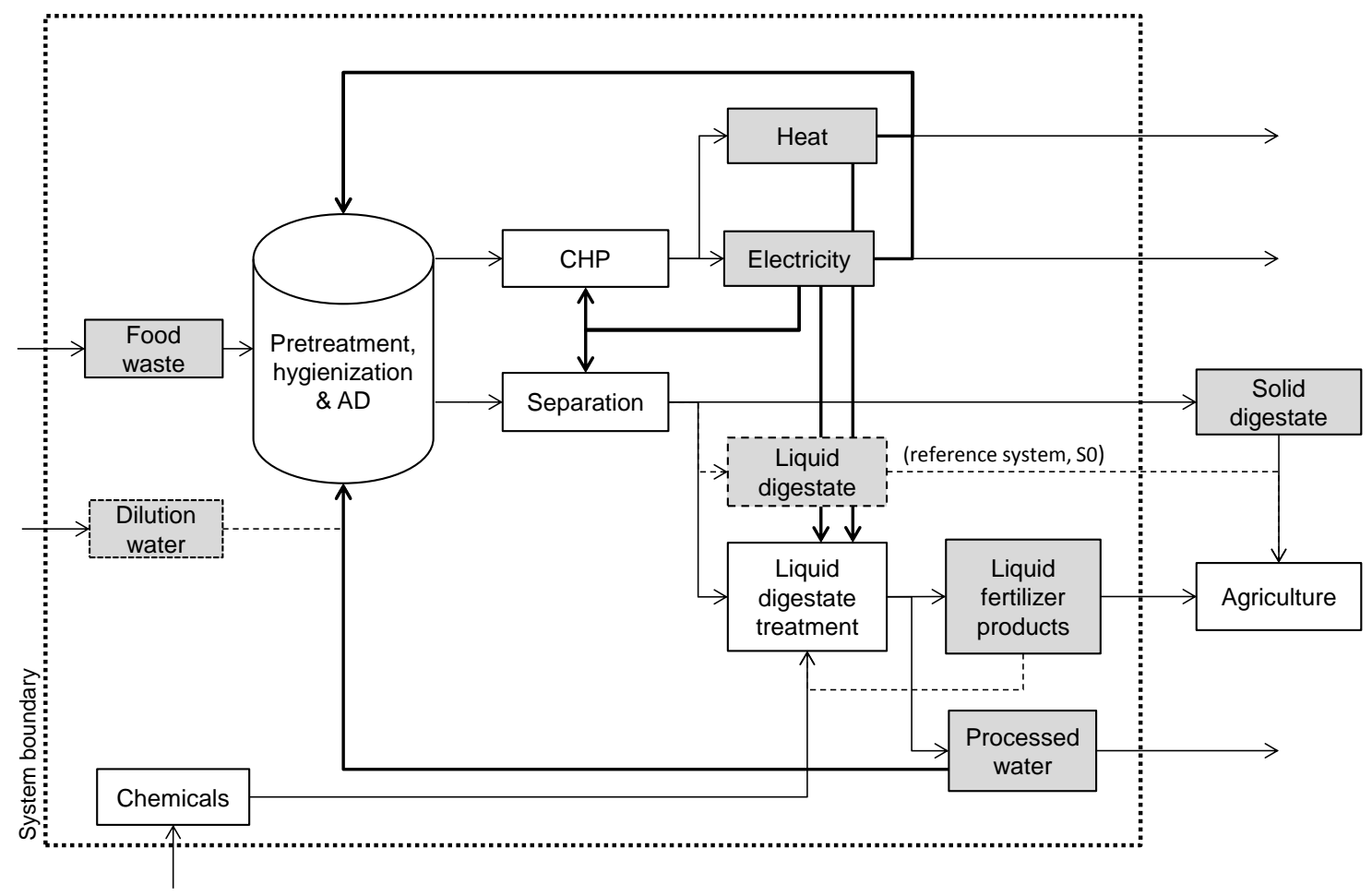


Fig. 2.

\begin{tabular}{|c|c|c|}
\hline & so & Pin \\
\hline
\end{tabular}

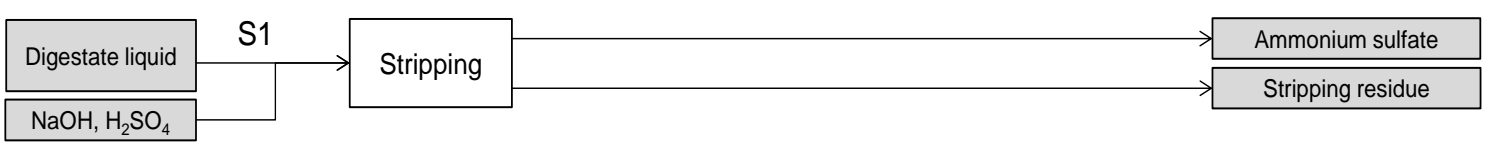

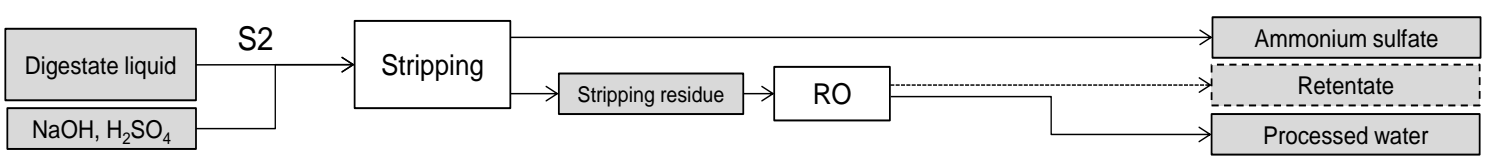

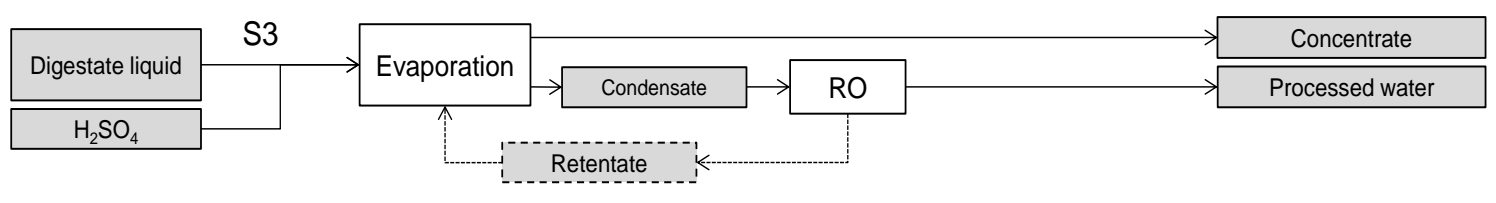

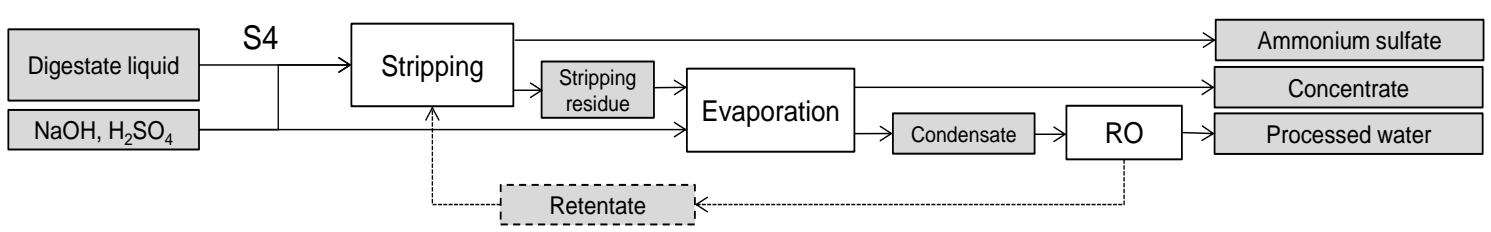


Fig. 3.

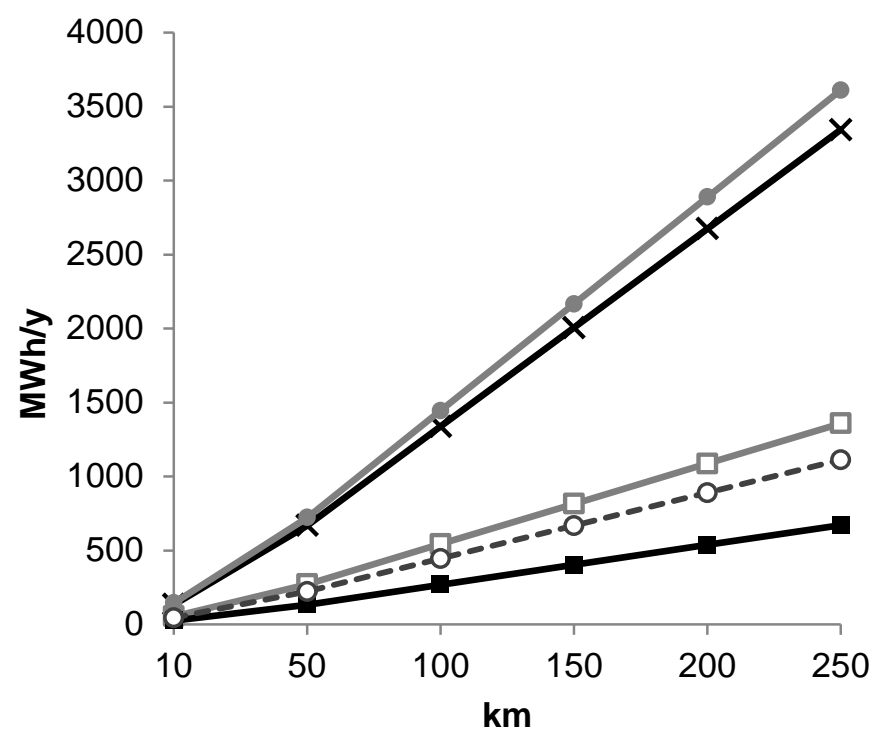

— $\mathrm{SO}$, liquid digestate $(79 \mathrm{kt} / \mathrm{y})$

$\longrightarrow \mathrm{S} 1$, ammonium sulfate + stripping residue $(85 \mathrm{kt} / \mathrm{y})$

$-\square$ S2, ammonium sulfate + retentate $(32 \mathrm{kt} / \mathrm{y})$

$\longrightarrow \mathrm{S} 3$, concentrate $(16 \mathrm{kt} / \mathrm{y})$

$-\infty-$ S4, ammonium sulfate + concentrate $(26 \mathrm{kt} / \mathrm{y})$ 
Supplementary Material for

Liquid fertilizer products from anaerobic digestion of food waste: mass, nutrient and energy balance of four digestate liquid treatment systems

Elina Tampio ${ }^{\mathrm{a}, \mathrm{b}, *}$, Sanna Marttinen ${ }^{\mathrm{c}}$, Jukka Rintala $^{\mathrm{b}}$

${ }^{a}$ Natural Resources Institute Finland (Luke), Bio-based Business and Industry, Tietotie

2 C, FI-31600, Jokioinen, Finland

${ }^{b}$ Tampere University of Technology, Department of Chemistry and Bioengineering, P.O. Box 541, FI-33101 Tampere, Finland

${ }^{c}$ Natural Resources Institute Finland (Luke), Bio-based Business and Industry, Viikinkaari 4, FI-00790, Helsinki, Finland

*Corresponding author: Tel.: +358 29532 6573, E-mail address: elina.tampio@luke.fi 


\section{Hygienization and digester}

\subsection{Mass balances}

The volume of methane produced during anaerobic digestion per year (AD, $\left.\mathrm{m}^{3} / \mathrm{y}\right)$ was calculated by multiplying the amount of volatile solids (VS) fed to the reactor (t/y) with the methane potential of the feedstock $\left(\mathrm{m}^{3} / \mathrm{tVS}\right)$. The mass of methane was calculated according to equation:

$m=V \times \rho / 1000$

where the $m$ is the mass of $\mathrm{CH}_{4}(\mathrm{tFM} / \mathrm{y}), V$ is the volume of $\mathrm{CH}_{4}\left(6.21 \mathrm{Mm}^{3} / \mathrm{y}\right)$ and $\rho$ is the density of $\mathrm{CH}_{4}\left(0.72 \mathrm{~kg} / \mathrm{m}^{3}\right)$.

The volume of $\mathrm{CO}_{2}$ annually produced in the $\mathrm{AD}$ was calculated using the carbon dioxide content (40\%), the assumed methane content (60\%) and the volume of methane $\left(6.21 \mathrm{Mm}^{3} / \mathrm{y}\right)$. The mass of $\mathrm{CO}_{2}$ was calculated the same way as the mass of $\mathrm{CH}_{4}$ using the $\mathrm{CO}_{2}$ density of $1.96 \mathrm{~kg} / \mathrm{m}^{3}$. Subsequently, the digestate mass was calculated by subtracting the biogas mass $\left(\mathrm{CH}_{4}+\mathrm{CO}_{2}, 12586 \mathrm{t} / \mathrm{y}\right)$ from the feedstock mass.

For the calculation of the mass balances of total solids (TS) and VS, it was assumed that the produced biogas was produced from TS and VS. Subsequently, the TS and VS contents of the produced digestate were calculated as the difference between feedstock TS or VS (t/y) and biogas mass ( $t / y)$. The nutrient content in digestate was assumed to be the same as in the feedstock except in the case of $\mathrm{NH}_{4}-\mathrm{N}$, which concentration was assumed to increase from $0.4 \mathrm{~g} / \mathrm{kg}$ fresh matter (FM) (feedstock) to 4 $\mathrm{g} / \mathrm{kgFM}$ (digestate) according to Tampio et al. (2014, 2015). 


\subsection{Energy balances}

In the hygienization unit the feedstock (60 kt of food waste) was heated to $75{ }^{\circ} \mathrm{C}$. The amount of energy needed for feedstock mixture heating was calculated with the specific heat capacity of water according to the equation:

$\Delta E=c \times m \times \Delta t$

where $\Delta \mathrm{E}$ is the energy needed for heating the feedstock mixture, $c$ is the specific heat capacity of water $\left(\mathrm{c}_{\text {water }}=4.18 \mathrm{~kJ} / \mathrm{kg}^{\circ} \mathrm{C}\right), m$ is the mass of the mixture $(\mathrm{kg})$ and $\Delta t$ is the change of the temperature (from 15 to $75^{\circ} \mathrm{C}$ ). For the digester, the amount of energy needed was allocated only for the dilution water $(40 \mathrm{kt} / \mathrm{y})$. This is because the heat from the hygienization unit was assumed to be sufficient for the heating of the FW feedstock (60 kt/y) (Berglund and Börjesson 2006, Prapaspongsa et al. 2010). The heating of water from 15 to $40{ }^{\circ} \mathrm{C}$ was calculated with the specific heat capacity of water as above. A similar method, based on the heat capacity of water for the calculation of the heat demand, was also used e.g. by Bacenetti et al. (2013), Rapport et al. (2011) and Smyth et al. (2009).

For the biogas production the conversion factor $1 \mathrm{~m}^{3}\left(\mathrm{CH}_{4}\right)=10 \mathrm{kWh}$ was used for the calculation of the energy content of the produced biogas.

Heat loss from the hygienization and digester was assumed to be $15 \%$ of the heat demand according to Smyth et al. (2009). Also higher values for digester heat loss have been reported, e.g., 20\% of the heat demand in Rapport et al. (2011).

The electricity and heat consumption during feed pretreatment and hygienization as well as during digestion and gas upgrading in CHP-unit (combined heat and power) were calculated according to the literature values (Table S1). The CHP efficiency was also chosen according to the literature information (Table S1). 
Table S1. Energy consumption of hygienization and pretreatment, anaerobic digestion and gas upgrading in CHP obtained from the literature and values chosen for the calculations.

\begin{tabular}{|c|c|c|c|}
\hline $\begin{array}{l}\text { Energy } \\
\text { consumption }\end{array}$ & Electricity & Heat & Reference \\
\hline \multicolumn{4}{|c|}{ Pretreatment + hygienization } \\
\hline & $150 \mathrm{kWh} / \mathrm{tTS}$ & $10 \%$ of heat in CHP & reviewed in Pöschl et al. 2010 \\
\hline & $37.5 \mathrm{kWh} / \mathrm{t}$ & Calculated value & Present study \\
\hline \multicolumn{4}{|l|}{ Digester } \\
\hline & $\begin{array}{l}3 \% \text { biogas } \\
\left(18.6 \mathrm{kWh} / \mathrm{t}^{\mathrm{a}}\right)\end{array}$ & $\begin{array}{l}9.6 \% \text { biogas } \\
(55.8 \mathrm{kWh} / \mathrm{t})^{\mathrm{a}}\end{array}$ & reviewed in Pöschl et al. 2010 \\
\hline & $7.5 \%$ of electricity in CHP & $20 \%$ of heat in CHP & \\
\hline & $(17.7 \mathrm{kWh} / \mathrm{t})^{\mathrm{a}}$ & $(47.2 \mathrm{kWh} / \mathrm{t})^{\mathrm{a}}$ & $\begin{array}{l}\text { reviewed in Pöschl et al. } 2010 \\
\text { reviewed in Berglund and }\end{array}$ \\
\hline & $18(15-22) \mathrm{kWh} / \mathrm{t}$ & $31(19-50) \mathrm{kWh} / \mathrm{t}$ & Börjesson 2006 \\
\hline & $5 \mathrm{kWh} / \mathrm{t}$ biomass & $34 \mathrm{kWh} / \mathrm{m}^{3}$ raw material & DEA 2005 \\
\hline & $18 \mathrm{kWh} / \mathrm{t}$ & Calculated value & Present study \\
\hline \multicolumn{4}{|l|}{ CHP-unit } \\
\hline & $4.5 \%$ of electricity in $\mathrm{CHP}$ & - & Pöschl et al. 2010 \\
\hline & $6.3 \%$ of electricity in CHP & - & Havukainen et al. 2014 \\
\hline & $8.5-8.7 \%$ of electricity in CHP & - & Naegele et al. 2012 \\
\hline & $4.2 \%$ of electricity in CHP & - & Banks et al. 2011 \\
\hline & $5 \%$ of electricity in CHP & - & Present study \\
\hline \multicolumn{4}{|c|}{ CHP efficiency } \\
\hline & $40.9 \%$ & $44 \%$ & Bacenetti et al. 2013 \\
\hline & $37 \%$ & $47.1 \%$ & Bacenetti et al. 2013 \\
\hline & $35.7 \%$ & $51 \%$ & Bacenetti et al. 2013 \\
\hline & $40 \%$ & $48 \%$ & Poeschl et al. 2012 \\
\hline & $38 \%$ & $47 \%$ & Present study \\
\hline
\end{tabular}

${ }^{\mathrm{a}}$ Calculated with the results from the present study

-, not available 


\section{Digestate separation}

The digestate solid-liquid separation efficiency and energy consumption of a decanter centrifuge were based on the literature values (Table S2).

Table S2. Centrifuge separation efficiencies and energy consumption obtained from the literature and values chosen for the calculations. Separation efficiency presented as the percentage in the liquid fraction. Digestate (D), digestate liquid (DL), manure (M).

\begin{tabular}{|c|c|c|c|c|c|c|c|c|c|}
\hline \multicolumn{7}{|c|}{ Separation efficiency, \% } & \multirow{2}{*}{$\begin{array}{c}\text { Energy } \\
\text { Electricity } \\
\left(\mathrm{kWh} / \mathrm{m}^{3}\right. \\
\text { digestate }) \\
\end{array}$} & \multirow{2}{*}{ Material } & Reference \\
\hline Mass & TS & VS & $\mathrm{N}$ & $\mathrm{NH}_{4}-\mathrm{N}$ & $\mathrm{P}$ & $\mathrm{K}$ & & & \\
\hline - & $31-46$ & - & $69-76$ & & $9-48$ & - & $3.1-5.6$ & D & Møller et al. 2002 \\
\hline 91 & 36 & - & 72 & 89 & 10 & 99 & - & $\mathrm{DL}_{\mathrm{pig}}$ & Ledda et al. 2013 \\
\hline 76 & 17 & - & 48 & 81 & 4 & 77 & - & $\mathrm{DL}_{\mathrm{cow}}$ & $\begin{array}{l}\text { Ledda et al. } 2013 \\
\text { Melse and Verdoes }\end{array}$ \\
\hline 22.5 & - & - & 87 & - & 19 & 33.5 & $1.8-2.2$ & $\mathrm{M}_{\mathrm{pig}}$ & 2005 \\
\hline- & $38-67$ & - & $71-87$ & - & $34-40$ & - & $4.3-6.3$ & $\mathbf{M}_{\text {pig }}$ & Møller et al. 2002 \\
\hline - & $35-45$ & - & $51-73$ & - & $18-22$ & - & $4.3-7.3$ & $\mathrm{M}_{\text {cow }}$ & $\begin{array}{l}\text { Møller et al. } 2002 \\
\text { reviewed in Hjorth et }\end{array}$ \\
\hline $75-95$ & $5-66$ & - & $46-99$ & $72-92$ & $9-52$ & - & - & $\mathrm{M}_{\text {pig, cow }}$ & al. 2010 \\
\hline- & - & - & - & - & - & - & $2-4$ & - & Flotats et al. 2011 \\
\hline - & - & - & - & 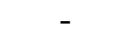 & - & - & 3 & - & Møller et al. 2000 \\
\hline 90 & 20 & 20 & 70 & 81 & 10 & 85 & 3.5 & - & Present study \\
\hline
\end{tabular}




\section{Stripping of digestate liquid}

The digestate liquid stripping efficiency and energy consumption were based on the literature values (Table S3). The heat demand of the stripping was calculated with the temperature change between digester $\left(40^{\circ} \mathrm{C}\right)$ and stripper $\left(80^{\circ} \mathrm{C}\right)$ using the heating capacity of water as in Chapter 1.2 of the Supplementary material.

Table S3. Recovery efficiency, process parameters and energy consumption of stripping obtained from the literature and values chosen for the calculations. Recovery efficiency presented as percentage in ammonium sulfate. Digestate (D), manure (M), digestate liquid (DL), urine (U).

\begin{tabular}{|c|c|c|c|c|c|c|c|}
\hline \multicolumn{2}{|c|}{$\begin{array}{c}\text { Recovery } \\
\text { efficiency (\%) }\end{array}$} & \multicolumn{2}{|c|}{ Process parameters } & \multirow{2}{*}{$\begin{array}{c}\text { Consumption } \\
\text { Energy } \\
(\mathrm{kWh} / \mathrm{kgN} \\
\text { recovered) }\end{array}$} & \multirow[t]{2}{*}{ Scale } & \multirow[t]{2}{*}{ Material } & \multirow[t]{2}{*}{ Reference } \\
\hline $\mathrm{N}$ & $\mathrm{NH}_{4}-\mathrm{N}$ & $\mathrm{pH}$ & $\begin{array}{l}\text { Tempera- } \\
\text { ture }\left({ }^{\circ} \mathrm{C}\right)\end{array}$ & & & & \\
\hline- & 97 & - & 35 & - & lab & $\mathrm{D}$ & Liu et al. 2015 \\
\hline - & $>96$ & $8.5-11.5$ & 80 & - & lab & $\mathrm{D}$ & Bonmatí and Flotats 2003a \\
\hline- & $>80$ & 9.5 & $40-50$ & - & lab & $\mathrm{D}, \mathrm{M}_{\mathrm{pig}}$ & $\begin{array}{l}\text { Laureni et al. } 2013 \\
\text { Guštin and Marinšek-Logar }\end{array}$ \\
\hline $65-80$ & $80-92.2$ & $8.5-11$ & $30-70$ & - & pilot & DL & 2011 \\
\hline $65-76$ & - & $9-9.5$ & 60 & - & full & DL & Morales et al. 2013 \\
\hline 94 & - & 10 & 40 & $18.8-28.2^{\mathrm{a}}$ & pilot & $\mathrm{U}$ & Antonini et al. 2011 \\
\hline- & 92 & 12 & 16 & 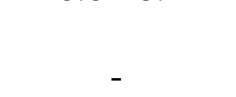 & lab & $\mathrm{U}$ & $\begin{array}{l}\text { Basakcilardan-Kabakci et al. } \\
\qquad 2007\end{array}$ \\
\hline- & $65-98.8$ & $7.7-11.5$ & 80 & - & lab & $\mathrm{M}_{\mathrm{pig}}$ & Bonmatí and Flotats 2003a \\
\hline 90 & - & 9.3 & 60 & $11-14$ & full & - & reviewed in Morales et al. 2013 \\
\hline- & - & - & - & $\begin{array}{c}7.3 \text { (aeration) } \\
0.8-23\end{array}$ & - & - & $\begin{array}{l}\text { reviewed in Mauer et al. } 2003 \\
\text { reviewed in van Eekert et al. }\end{array}$ \\
\hline- & - & - & - & (electricity) & - & - & 2012 \\
\hline - & 95 & $9-10$ & $<100$ & - & _ & _ & Flotats et al. 2011 \\
\hline - & 95 & - & 80 & $2+$ heat $^{\mathrm{b}}$ & - & - & Present study \\
\hline
\end{tabular}

${ }^{\mathrm{a}} \mathrm{kWh} / \mathrm{kg} \mathrm{NH} \mathrm{NH}_{4} \mathrm{~N}$

${ }^{\mathrm{b}}$ Calculated with the specific heat capacity of water

,- not available

\section{Reverse osmosis treatment for stripping residue and condensate}

The recovery efficiency and energy consumption of the reverse osmosis (RO) treatment were based on the literature values (Table S4). 
Table S4. Recovery efficiency, process parameters and energy consumption of reverse osmosis obtained from the literature and values chosen for the calculations. Recovery efficiency presented as percentage in retentate. Digestate (D), digestate liquid (DL), urine (U), sewage reject water $(\mathrm{S})$, manure $(\mathrm{M})$.

\begin{tabular}{|c|c|c|c|c|c|c|c|c|c|c|c|c|c|}
\hline \multicolumn{7}{|c|}{ Separation/recovery efficiency, $\%$} & \multicolumn{3}{|c|}{ Process parameters } & \multirow{2}{*}{$\begin{array}{c}\text { Consumption } \\
\text { Energy }\left(\mathrm{kWh} / \mathrm{m}^{3}\right. \\
\text { stripping } \\
\text { residue/condensate) }\end{array}$} & \multirow[t]{2}{*}{ Scale } & \multirow[t]{2}{*}{ Material } & \multirow[t]{2}{*}{ Reference } \\
\hline Mass & TS & VS & $\mathrm{N}$ & $\mathrm{NH}_{4}-\mathrm{N}$ & $\mathrm{P}$ & $\mathrm{K}$ & $\mathrm{pH}$ & $\begin{array}{c}\text { Tempera } \\
\text {-ture } \\
\left({ }^{\circ} \mathrm{C}\right)\end{array}$ & $\begin{array}{l}\text { Pres- } \\
\text { sure } \\
\text { (bar) }\end{array}$ & & & & \\
\hline- & - & - & - & - & - & - & - & - & $10-30$ & $2.5-10$ & lab & $\mathrm{D}$ & Carretier et al. 2015 \\
\hline 28 & $86-100$ & - & 99.7 & 99.6 & 72 & 99.5 & - & - & - & - & full & DL & Ledda et al. 2013 \\
\hline 29 & $97-100$ & - & 97 & 97 & 100 & 99 & - & - & - & - & full & DL & Ledda et al. 2013 \\
\hline 28 & - & - & - & - & - & - & - & - & - & - & full & $\mathrm{DL}$ & Chiumenti et al. 2010 \\
\hline- & - & - & 90 & - & 92 & 97 & $6-9.2$ & $10-45$ & - & (heat) & lab & $\mathrm{S}$ & Ek et al. 2006 \\
\hline- & 92.3 & $98-100$ & - & 66 & - & - & 8.8 & 22.5 & 55 & & lab & $\mathrm{M}_{\text {pig }}^{\mathrm{a}}$ & Mondor et al. 2008 \\
\hline- & - & 99 & - & 99.5 & - & - & - & - & $10-100$ & $1.5-10$ & - & - & Flotats et al. 2011 \\
\hline 28 & 100 & 100 & - & 95 & 95 & 99 & - & - & - & 2.5 & - & - & Present study \\
\hline
\end{tabular}

${ }^{\mathrm{a}}$ After electrodialysis treatment

-, not available 


\section{5. Evaporation treatment for digestate liquid and stripping residue}

2 The digestate liquid evaporation efficiency and energy consumption were based 3 on the literature values (Table S5). The heat demand of evaporation was calculated as 4 the temperature change between the digester $\left(40{ }^{\circ} \mathrm{C}\right)$ and evaporator $\left(80{ }^{\circ} \mathrm{C}\right)$ using the 5 heating capacity of water as in Chapter 1.2 of the Supplementary material. In system 6 stripping + evaporation $+\mathrm{RO}$ (S4) no heat was allocated for evaporation, thus it was 7 assumed that heat from the stripping $\left(80^{\circ} \mathrm{C}\right)$ was sufficient for the evaporation as was 8 presented in Ervasti et al. (2011).

9 Table S5. Recovery efficiency, process parameters and energy consumption of 10 evaporation obtained from the literature and values chosen for the calculations.

11 Recovery efficiency presented as percentage in concentrate. Digestate (D), digestate 12 urine (U), sewage reject water (S).

\begin{tabular}{|c|c|c|c|c|c|c|c|c|c|c|}
\hline \multicolumn{4}{|c|}{ Recovery efficiency, \% } & \multicolumn{3}{|c|}{ Process parameters } & \multirow{2}{*}{$\begin{array}{c}\text { Consumption } \\
\text { Energy }\left(\mathrm{kWh} / \mathrm{m}^{3}\right. \\
\text { digestate liquid or } \\
\text { stripping residue) }\end{array}$} & \multirow[t]{2}{*}{ Scale } & \multirow[t]{2}{*}{ Material } & \multirow[t]{2}{*}{ Reference } \\
\hline Mass & $\mathrm{N}$ & $\mathrm{P}$ & K & $\mathrm{pH}$ & $\begin{array}{l}\text { Temper } \\
\text {-ature } \\
\left({ }^{\circ} \mathrm{C}\right) \\
\end{array}$ & $\begin{array}{l}\text { Pres- } \\
\text { sure } \\
\text { (bar) }\end{array}$ & & & & \\
\hline - & $80-84$ & $84-96$ & $90-99$ & $5.9-6.5$ & 40 & 6.7 & - & lab & $\mathrm{D}$ & $\begin{array}{c}\text { Bonmatí and } \\
\text { Flotats } 2003 \mathrm{~b} \\
\text { Chiumenti et }\end{array}$ \\
\hline 20.2 & 99.2 & - & - & $3.5-5$ & 35 & 5.3 & $1.9^{\mathrm{a}}$ (electricity) & - & $\mathrm{D}$ & $\begin{array}{l}\text { al. } 2013 \\
\text { Mauer et al. }\end{array}$ \\
\hline 10 & - & - & - & - & 78 & 0.2 & $\begin{array}{l}3^{\mathrm{a}} \text { (fuel) } \\
30 \text { (electricity) } 0\end{array}$ & - & $\mathrm{U}$ & 2003 \\
\hline- & 95 & 100 & 99 & $4.5-5.5$ & $>30$ & - & $\begin{array}{c}\text { (heat) } \\
30 \text { (electricity) } 0\end{array}$ & lab & $\mathrm{U}$ & Ek et al. 2006 \\
\hline- & 95 & 100 & 100 & $4.5-5.5$ & $>30$ & - & $\begin{array}{l}\text { (heat) } \\
21 \text { (electricity) }\end{array}$ & lab & $S$ & $\begin{array}{c}\text { Ek et al. } 2006 \\
\text { Flotats et al. }\end{array}$ \\
\hline $15-20$ & 98 & - & - & $<5.5$ & - & - & $107-353$ (heat) & - & - & 2011 \\
\hline 20 & 90 & 100 & 100 & - & 80 & - & $30+$ heat $^{\mathrm{b}}$ & - & - & Present study \\
\hline
\end{tabular}

${ }^{\mathrm{a}} \mathrm{kWh} / \mathrm{kgN}$

${ }^{\mathrm{b}}$ Calculated with the specific heat capacity of water -, not available 
References

Antonini, S., Paris, S., Eichert, T., Clemens, J., 2011. Nitrogen and phosphorus recovery

16 from human urine by struvite precipitation and air stripping in Vietnam. Clean -Soil Air Water $1739,1099-1104$.

Bacenetti, J., Negri, M., Fiala, M., González-García, S., 2013. Anaerobic digestion of different feedstocks: Impact on energetic and environmental balances of biogas process. Sci Total Environ 463-464, 541-551.

Banks, C., Chessire, M., Heaven, S., Arnold, R. 2011. Anaerobic digestion of sourcesegregated domestic food waste: Performance assessment by mass and energy balance.

23 Bioresour Technol 102, 612-620.

Basakcilardan-Kabakci, S., Ipekoglu, A.N., Talini, I., 2007. Recovery of ammonia from human urine by stripping and absorption. Environ Eng Sci 24, 615-624.

Berglund, M., Börjesson, P., 2006. Assessment of energy performance in the life-cycle of biogas production. Biomass Bioenerg 30, 254-266.

Bonmatí, A., Flotats, X., 2003a. Air stripping of ammonia from pig slurry: characterization and feasibility as a pre- or post-treatment to mesophilic anaerobic digestion.

30 Waste Manage 23, 261-272.

Bonmatí, A., Flotats, X., 2003b. Pig slurry concentration by vacuum evaporation: influence of previous mesophilic anaerobic digestion process. J Air \& Waste Manage Assoc 53, $21-31$. from livestock manure by membrane processes. Can J Chem Eng 93, 225-233.

Chiumenti, R., Chiumenti, A., da Borso, F., 2010. Digestate treatment by means of a full scale membrane system: an innovative method for managing surplus nitrogen and for valorizing farm effluents. Ramiran 2010, $14^{\text {th }}$ Ramiran International Conference, Lisbon, Portugal, 12-15 September, 2010.

40 Chiumenti, A., da Borso, F., Chiumenti, R., Teri, F., Segantin, P., 2013. Treatment of digestate from a co-digestion biogas plant by means of vacuum evaporation: Tests for process optimization and environmental sustainability. Waste Manage 33, 1339-1344. 
DEA, 2005. Technology data for energy plants. Generation of electricity and district heating, energy storage and energy carrier generation and conversion. Danish Energy Agency, 46 2012. Available at

47 https://www.energinet.dk/SiteCollectionDocuments/Danske\%20dokumenter/Forskning/Technol ogy_data_for_energy_plants.pdf [accessed on 25.6.2015]

Ek, M., Bergström, R., Bjurhem, J.-E., Björlenius, B., Hellström, D., 2006. Concentration of nutrients from urine and reject water from anaerobically digested sludge. Water Sci Technol $54,437-444$.

Ervasti, S., Paavola, T., Rintala, J., 2011. Recovery of nitrogen and phosphorus from biogas plant digestate with combined ammonia stripping and water evaporation. International IWA-Symposium on Anaerobic Digestion of Solid Waste and Energy Crops, August 28September 01, 2011, Vienna, Austria.

Flotats, X., Foged, H.L., Bonmati Blasi, A., Palatsi, J., Magri, A., Schelde, K.M., 2011. Manure processing technologies. Technical Report No. II concerning "Manure Processing Activities in Europe" to the European Commission, Directorate-General Environment. 184 pp. Available at http://agro-technologyatlas.eu/docs/21010_technical_report_II_manure_processing_technologies.pdf [accessed on 11.06.2015]

Guštin, S., Marinšek-Logar, R., 2011. Effect of pH, temperature and air flow rate on the continuous ammonia stripping of the anaerobic digestion effluent. Process Saf Environ 89, 6166.

Havukainen, J., Uusitalo, V., Niskanen, A., Kapustina, V., Horttanainen, M., 2014. Evaluation of methods for estimating energy performance of biogas production. Renew Energ $6766,232-240$.

Hjorth, M., Christensen, K.V., Christensen, M.L., Sommer, S.G., 2010. Solid-liquid separation of animal slurry in theory and practice. A review. Agron Sustain Dev 30, 153-180. characteristics on ammonia stripping efficiencies and quality of the recovered ammoniumsulfate solution. J Chem Technol Biotechnol 88, 1654-1662. animal slurries by a new integrated ultrafiltration, reverse osmosis and cold stripping process: A case study. Water Res 47, 6165-6166. 
Liu, L., Pang, C., Wu, S., Dong, R., 2015. Optimization and evaluation of air-recirculated stripping for ammonia removal from the anaerobic digestate of pig manure. Process Saf Environ 94, 350-357.

Mauer, M., Schwegler, P., Larsen, T.A., 2003. Nutrients in urine: energetic aspect of removal and recovery. Water Sci Technol 48, 37-46.

Melse, R.W., Verdoes, N., 2005. Evaluation of four farm-scale systems for the treatment of liquid pig manure. Biosyst Eng 92, 47-57.

Mondor, M., Masse, L., Ippersiel, D., Lamarche, F., Massé, D.I., 2008. Use of electrodialysis and reverse osmosis for the recovery and concentration of ammonia from swine manure. Bioresour Technol 99, 7363-7368.

Morales, N., Boehler, M.A., Buettner, S., Liebi, C., Siegrist, H., 2013. Recovery of N and $\mathrm{P}$ from urine by struvite precipitation followed by combined stripping with digester sludge liquid at full scale. Water 5, 1262-1278.

Møller, H.B., Lund, I., Sommer, S.G., 2000. Solid-liquid separation of livestock slurry: efficiency and cost. Bioresour Technol 74, 223-229.

Møller, H.B., Sommer, S.G., Ahring, B.K., 2002. Separation efficiency and particle size distribution in relation to manure type and storage conditions. Bioresour Technol 85, 189-196.

Naegele, H.J., Lemmer, A., Oechsner, H., Jungbluth, T. 2012. Electric energy consumption of the full scale research biogas plant "Unterer Lindenhof": Results of longterm and full detail measurements. Energies 5, 5198-5214.

Poeschl, M., Ward, S., Owende, P., 2012. Environmental impacts of biogas deployment Part I: life cycle inventory for evaluation of production process emissions to air. J Clean Prod $24,168-183$.

Prapaspongsa, T., Poulsen, T.G., Hansen, J.A., Christensen, P., 2010. Energy production, nutrient recovery and greenhouse gas emission potentials from integrated pig manure management systems. Waste Manage Res 28, 411-422.

Pöschl, M., Ward, S., Owende, P., 2010. Evaluation of energy efficiency of various biogas production and utilization pathways. Appl Energ 87, 3305-3321.

Rapport, J.L., Zhang, R., Jenkins, B.M., Hartsough, B.R., Tomich, T.P., 2011. Modeling the performance of the anaerobic phased solids digester system for biogas energy production. Biomass Bioenerg 35, 1263-1272. 
107 Smyth, B.M., Murphy, J.D., O’Brien, C.M., 2009. What is the energy balance of grass

108 biomethane in Ireland and other temperate northern European climates? Renew Sust Energ Rev

109 13, 2349-2360.

110 Tampio, E., Ervasti, S., Paavola, T., Heaven, S., Banks, C., Rintala, J., 2014. Anaerobic

111 digestion of untreated and autoclaved food waste. Waste Manage 34, 370-377.

112 Tampio, E., Ervasti, S., Rintala, J., 2015. Characteristics and agronomic usability of

113 digestates from laboratory digesters treating food waste and autoclaved food waste. J Clean

114 Prod 94, 86-92.

115 van Eekert, M., Weijma, J., Verdoes, N., de Buisonjé, F., Reitsma, B., van der Bulk, J.,

116 van Gastel, J., 2012. Explorative research on innovative nitrogen recovery. Rapport 51, 2012.

117 STOWA. Available at:

118 http://www.stowa.nl/Upload/publicaties/STOWA\%202012\%2051_LR.pdf [accessed on

119 25.6.2015]

120

121 